\title{
The Effects of 3-Phosphoglycerate and Other Metabolites on the Activation of AMP-Activated Protein Kinase by LKB1/STRAD/ MO25
}

William John Ellingson

Brigham Young University - Provo

Follow this and additional works at: https://scholarsarchive.byu.edu/etd

Part of the Cell and Developmental Biology Commons, and the Physiology Commons

\section{BYU ScholarsArchive Citation}

Ellingson, William John, "The Effects of 3-Phosphoglycerate and Other Metabolites on the Activation of AMP-Activated Protein Kinase by LKB1/STRAD/MO25" (2006). Theses and Dissertations. 485.

https://scholarsarchive.byu.edu/etd/485

This Thesis is brought to you for free and open access by BYU ScholarsArchive. It has been accepted for inclusion in Theses and Dissertations by an authorized administrator of BYU ScholarsArchive. For more information, please contact scholarsarchive@byu.edu, ellen_amatangelo@byu.edu. 
THE EFFECTS OF 3-PHOSPHOGLYCERATE AND OTHER

\author{
METABOLITES ON THE ACTIVATION OF AMP- \\ ACTIVATED PROTEIN KINASE BY \\ LKB1/STRAD/MO25
}

by

William J. Ellingson

A thesis submitted to the faculty of

Brigham Young University

In partial fulfillment of the requirements for the degree of

\author{
Master of Science
}

Department of Physiology and Developmental Biology

Brigham Young University

August 2006 


\title{
BRIGHAM YOUNG UNIVERSITY
}

\section{GRADUATE COMMITTEE APPROVAL}

\author{
of a thesis submitted by
}

\author{
William J. Ellingson
}

This thesis has been read by each member of the following graduate committee and by majority vote has been found to be satisfactory.

Date

Date

Date
Steven W. Graves

William W. Winder, Chair

James P. Porter 


\section{BRIGHAM YOUNG UNIVERSITY}

As chair of the candidate's graduate committee, I have read the thesis of William J. Ellingson in its final form and have found that (1) its format, citations, and bibliographical style are consistent and acceptable and fulfill university and department style requirements; (2) its illustrative materials including figures, tables, and charts are in place; and (3) the final manuscript is satisfactory to the graduate committee and is ready for submission to the university library.

Date

William W. Winder

Chair, Graduate Committee

Accepted for the Department

Dixon J. Woodbury

Graduate Coordinator

Accepted for the College

Rodney J. Brown

Dean, College of Biology and Agriculture 
ABSTRACT

THE EFFECTS OF 3-PHOSPHOGLYCERATE AND OTHER METABOLITES ON THE ACTIVATION OF AMPACTIVATED PROTEIN KINASE BY LKB1/STRAD/MO25

William J. Ellingson

Department of Physiology and Developmental Biology Master of Science

Skeletal muscle contraction results in the phosphorylation and activation of the AMP-activated protein kinase (AMPK) by an upstream kinase, AMPKK. The LKB1/STRAD/MO25 complex (LSMK) is the major AMPKK in skeletal muscle; however, LSMK activity is not increased by muscle contraction. This relationship suggests that phosphorylation of AMPK by LSMK during skeletal muscle contraction may be regulated by allosteric mechanisms. In this study we tested an array of metabolites including glucose-6-phosphate (G6P), fructose-6-phosphate (F6P), fructose 1,6-bisphosphate (F1,6- $\left.\mathrm{P}_{2}\right)$, 3-phosphoglycerate (3PG), glucose-1-phosphate (G1P), glucose-1,6-bisphosphate (G1,6- $\left.\mathrm{P}_{2}\right)$, adenosine diphosphate (ADP), carnitine (Carn), acetyl-carnitine (Acarn), inosine monophosphate (IMP), inosine, and ammonia to test for allosteric regulation. We found that 3PG stimulated LSMK activity and 
allowed for increased AMPK phosphorylation. 3PG did not stimulate LSMK activity toward the peptide substrate LKB1tide. The stimulatory effect that 3PG has with AMPK activation was determined to be an allosteric effect. These results have identified 3PG as an AMPK-specific allosteric regulator of AMPK activation by LSMK. 


\section{ACKNOWLEDGEMENTS}

I would like to thank Dr. Winder for his expert tutelage and wisdom during the course of this project. I thank Dr. Eric Taylor for teaching me the fine points of scientific experimentation. Thanks also go out to all of the many people who have come and gone through the Winder lab and have helped me in so many ways. Finally, I thank my wife for her endless support and encouragement. 


\section{TABLE OF CONTENTS}

PROSPECTUS OF THESIS

Introduction 1

AMPK 1

AMPK Activation $\quad 2$

Regulation of Fatty Acid Oxidation by AMPK 3

Regulation of Glucose Uptake by AMPK 3

LKB1 as an AMPKK 3

AMPKK and Exercise $\quad 4$

Metabolite Changes During Exercise $\quad 5$

$\begin{array}{ll}\text { Sphingolipids and Exercise } & 7\end{array}$

$\begin{array}{ll}\text { Hypothesis } & 8\end{array}$

Proposed Experiments $\quad 8$

Methods $\quad 9$

References 12

THE EFFECTS OF 3-PHOSPHOGLYCERATE AND OTHER

METABOLITES ON ACTIVATION OF AMP-ACTIVATED

PROTEIN KINASE BY LKB1/STRAD/MO25

Abstract $\quad 21$

Introduction $\quad 22$

Materials and Methods $\quad 23$

$\begin{array}{ll}\text { Results } & 27\end{array}$

Discussion $\quad 31$

References

Figure Legends $\quad 45$

$\begin{array}{ll}\text { Figures } & 48\end{array}$

Curriculum Vitae $\quad 56$ 


\section{TABLE OF FIGURES}

Figure $1 A$ and $B$

Figure $1 C$ and $D$

Figure 2

Figure 3

Figure 4

Figure 5

Figure 6

54

Figure 7

55 


\section{Introduction}

The AMP-activated protein kinase (AMPK) is a master metabolic regulator found to regulate fatty acid oxidation and glucose uptake. AMPK is able to sense the rapid rise in the AMP-to-ATP ratio that accompanies skeletal muscle stimulation, and as a result, become active. AMPK is activated by both AMP and an upstream kinase, AMPKK, composed of three complexed proteins, LKB1, STE-related adaptor (STRAD), and mouse protein 25 (MO25). During a bout of exercise, AMPK activation increases in skeletal muscle while the apparent AMPKK activity does not change. During muscle contraction, changes are also observed in the content of intracellular skeletal muscle metabolites and lipids. A possible explanation for why no increase in AMPKK activity is observed during endurance exercise is that AMPKK activity is altered by the change in the intramuscular metabolites and lipids, and not via covalent modification. This could be accomplished by either allosteric effects on AMPKK or at the substrate level, making AMPK a better substrate for AMPKK. This study will investigate whether the changes in the intracellular environment during skeletal muscle exercise will have allosteric effects on AMPKK.

\footnotetext{
AMPK

AMPK is a heterotrimeric protein containing $\alpha, \beta$, and $\gamma$ subunits. Each subunit can be found in different isoforms: the $\alpha$ subunit can be either $\alpha 1$ or $\alpha 2$; the $\beta$ subunit can be either $\beta 1$ or $\beta 2$; and the $\gamma$ subunit can be either $\gamma 1, \gamma 2$, or $\gamma 3$. The most common isoforms in most cells are the $\alpha 1, \beta 1$, and $\gamma 1$. However, in skeletal and
} 
cardiac muscle, $\alpha 2, \beta 2, \gamma 2$, and $\gamma 3$ are also expressed $(6,44,48)$. The $\alpha$ subunit contains the catalytic

domain, where AMPK activation occurs at threonine-172 by an upstream AMPK kinase (AMPKK) (21). The $\gamma$ subunit contains four specialized Cystathione Beta Synthase (CBS) domains, which create two AMP binding sites termed Bateman domains. The binding of AMP to the first Bateman domain works cooperatively to increase the binding affinity of a second AMP. Once AMP is bound, the $\alpha$ subunit is then exposed for phosphorylation at threonine-172.

\section{AMPK Activation}

AMPK activation is a two-step process: first, AMP binding to the Bateman domains of the $\gamma$ subunit, and second, phosphorylation at threonine-172 of the $\alpha$ subunit. AMPK monitors the AMP:ATP ratio within the cells of the body; when AMP levels rise and ATP levels decline, more AMP is available for binding to the Bateman domains. Due to this relationship, AMPK can be chemically stimulated by 5-amino-4-imidazolecarboxamide riboside (AICAR), which after entering the cell is converted into an AMP analog 5-amino-4-imidazolecarboxamide ribotide (ZMP) (26).

AMPK activation can occur during muscle contraction (55). During muscle contraction, there is a rapid change in the AMP-to-ATP ratio. This rapid rise in AMP will allosterically activate $\operatorname{AMPK}(5,8,21)$. AMPK activation during exercise or artificial electrical stimulation is dependent on the muscle work rate $(31,38)$. At low work rates in humans, AMPK is not activated, whereas higher work rates will cause AMPK activation $(15,57)$. 


\section{Regulation of Fatty Acid Oxidation by AMPK}

Activated AMPK modulates fatty acid oxidation through its inhibitory effects on acetyl-CoA carboxylase (ACC) $(35,55,56)$. ACC is a major component of the fatty acid synthesis pathway. AMPK stops ACC activity upon AMPK phosphorylation of ACC. When ACC is inactivated, levels of malonyl-CoA, a product of ACC, decrease. This drop in malonyl-CoA concentration removes the inhibitory effects that malonyl-CoA has on the enzyme carnitine palmitoyltransferase 1 (CPT-1). CPT-1 participates in the rate limiting step of fatty acid transport into mitochondria for oxidation. Thus, by removing the inhibitions on CPT-1 through ACC inactivation, AMPK regulates the degree to which a cell undergoes fatty acid oxidation.

\section{Regulation of Glucose Uptake by AMPK}

The skeletal muscle glucose transporter, GLUT-4 is an insulin-sensitive transporter, which resides in two locations in the muscle $(16,17,23,28)$. In the low insulin state, GLUT-4 resides in microvesicles beneath the sarcolemma and T-tubule membranes. In response to contraction, these transporters are then translocated to the membranes of the T-tubules and sarcolemma, allowing for increased glucose transport into the muscle fiber. AMPK has been identified as a major modulator of contractioninduced GLUT-4 translocation $(2,22,33)$.

\section{LKB1 as an AMPKK}

The protein LKB1 has been found to have AMPKK capabilities. LKB1 was first characterized as a tumor-suppressor kinase. LKB1 is a serine/threonine kinase 
also known as STK11, which was identified in 1998 to be the gene that is mutated in Peutz-Jeghers syndrome (PJS) (25). PJS individuals develop benign polyps in the gastrointestinal tracts with increased probability of developing malignant tumors in other tissues such as the liver. In 2003, LKB1 was shown to be activated through its interaction with STE20-related adaptor (STRAD) (1) and mouse protein 25 (MO25) (3). It appears as though STRAD acts as a cytoplasmic anchor, while MO25 acts as a scaffolding protein for the LKB1/STRAD/MO25 complex. Hawley et al. also found in 2003, that the LKB1/STRAD/MO25 complex has the ability to be a constitutively active AMPK kinase, phosphorylating AMPK at threonine-172 (20). They found through western blotting that when the three proteins were present, phospho-AMPK (P-AMPK) levels were high, whereas in the absence of one or more of the proteins, PAMPK was lowered. The lowest P-AMPK levels were found when LKB1 was removed through immunoprecipitation.

The role of LKB1 as the major AMPKK was demonstrated through a muscle specific LKB1 knockout (41). Mice that expressed the LKB1 knockout in muscle tissue experienced an enormous decrease in the production of P-AMPK and a decrease in phosphorylation of the downstream target of AMPK, ACC. Glucose uptake stimulated by AICAR and contraction was inhibited. These data demonstrate the integral role that LKB1 has in AMPKK function.

\section{AMPKK and Exercise}

Single bouts of endurance exercise and muscle stimulation have been shown to increase AMPK activity $(22,30,40,51)$ as well as P-AMPK abundance $(12,36)$ in 
non-trained tissues as well as trained tissues $(12,29,36)$. Along with P-AMPK, endurance training will increase the abundance of the proteins LKB1 and MO25 (29, $46,47)$. STRAD has not been shown to increase during endurance training due to an unavailability of STRAD antibodies for Western blotting. Due to these adaptations during endurance exercise and training, it is thought that AMPKK activity or LKB1 activity would likewise increase. However, no such increase has been found to be caused by a bout of contraction in non-trained tissues $(29,40)$, and trained tissues $(29$, 46, 47). There is a significant decrease in apparent AMPKK activity of trained tissues compared with non-trained tissues (29), and increased training duration showed further declines in AMPKK activity (47). These seemingly paradoxical findings suggest that AMPKK is activated during contraction by mechanisms other than covalent modification (29). It is possible that during contraction, the changes in the intracellular environment, particularly the concentrations of metabolites, lipids and other compounds, may either activate AMPKK allosterically or allow for AMPK to become a better substrate for AMPKK.

\section{Metabolite Changes During Exercise}

Upon skeletal muscle contraction, intramuscular changes occur, many of which involve energy production and regulation. When the process of glycolysis is activated upon skeletal muscle excitation and contraction, many of the glycolytic intermediates have changes in their concentrations. Molecules involved in glycogenolysis also change with contraction. Glucose 6-phosphate (G6P) concentrations increase $(24,32$, 37,42 ) from as low as $0.06 \mathrm{mM}$ to $1.96 \mathrm{mM}(27)$, fructose-6-phosphate (F6P) will 
increase $(37,53,54)$ from at least $0.018 \mathrm{mM}$ to $0.134 \mathrm{mM}(24)$, fructose-1,6bisphosphate (F1,6- $\left.\mathrm{P}_{2}\right)$ will increase (42) from as low as 0.004 (27) to $0.20 \mathrm{mM}(54)$, and 3-phosphoglycerate (3PG) will increase from as low as $0.4 \mathrm{mM}$ to $1.38 \mathrm{mM}$ (14). Glucose-1-phosphate (G1P) and glucose-1,6-diphosphate (G1,6- $\left.\mathrm{P}_{2}\right)$ are both involved in glycogen depletion and synthesis. G1P will change from $0.13 \mathrm{mM}$ to $0.39 \mathrm{mM}$ (24), while G1,6- $\mathrm{P}_{2}$ will increase from as low as $0.015 \mathrm{mM} \mathrm{(53)} \mathrm{to} 0.120 \mathrm{mM}$ (42). Adenosine diphosphate (ADP) $(24,37,43)$, carnitine and its acylated form, acetyl-carnitine $(7,39,50)$ levels all change with skeletal muscle exercise. ADP, a product of ATP breakdown (ATP $\rightarrow$ ADP $+\mathrm{P}_{\mathrm{i}}$ ) and involved in the myokinase reaction (2ADP $\rightarrow$ ATP + AMP), increases from $0.39 \mathrm{mM}(43)$ to $0.81 \mathrm{mM}(37)$. Carnitine and acetyl-carnitine are both involved in fatty acid oxidation. Carnitine will decrease from $3.18 \mathrm{mM}$ to $0.92 \mathrm{mM}$ (39) while acetyl-carnitine will increase from $0.46 \mathrm{mM}(50)$ to $3.62 \mathrm{mM}(39)$.

The purine nucleotide cycle (PNC) is important in maintaining a high cellular energy store. Members of the PNC including inosine monophosphate (IMP) (24, 58, $59)$, inosine $(13,19,59)$, and ammonia $(24,43)$, have been found to increase with exercise. IMP, the deaminated version of AMP, increases from at least $0.2 \mathrm{mM} \mathrm{(59)}$ to at least $3.4 \mathrm{mM} \mathrm{(58).} \mathrm{Inosine,} \mathrm{a} \mathrm{precursor} \mathrm{to} \mathrm{adenosine} \mathrm{and} \mathrm{uric} \mathrm{acid,} \mathrm{can} \mathrm{increase}$ from barely detectable levels to $0.25 \mathrm{mM}$ (13). Ammonia, part of the PNC and nitrogen cycle, can increase from $0.05 \mathrm{mM}$ to $0.51 \mathrm{mM}(24)$. 


\section{Sphingolipids and Exercise}

One of the major fractions of cellular phospholipids is sphingolipids.

Sphingolipids are part of a sphingolipid-sphingomyelin transmembrane signaling pathway. Their hydrolysis yields ceramide and phosphorylcholine. Ceramide has been recognized as the second messenger in the pathway. Ceramide is composed of a sphingoid base and a long-chain fatty acid joint in an amide bond. Ceramide can also be synthesized de novo from serine and palmitoyl-CoA, a known AMPKK inhibitor (45). Sphinganine is a key intermediate in the synthesis of ceramide from serine and palmitoyl-CoA. Once ceramide is synthesized, it can then be broken down to sphingosine and other down stream products.

Ceramide has been speculated to be involved in insulin sensitivity (18). Ceramide levels are elevated in obese, insulin-resistant Zucker rats (49). Further studies have shown that in the presence of ceramide, GLUT-4 translocation to cell membranes is inhibited $(4,52)$. Moreover, the post-exercise elevation in glucose uptake by different skeletal muscle types in rats was found to be inversely related to the total content of ceramide in the muscle (9).

In resting rat skeletal muscle, the three most prominent fatty acid side chains on ceramide are stearic $(\mathrm{C} 18)$, palmitic $(\mathrm{C} 16)$, and oleic $(\mathrm{C} 18: 1)$ acids. Concentrations of these ceramide fatty acids and others decrease with exercise. C18 levels decrease from at least $55.9 \mu \mathrm{M}$ (9) to 18.0 (11) $\mu \mathrm{M}, \mathrm{C} 16$ decreases from about $45.0 \mu \mathrm{M}$ (9) to 13.6 $\mu \mathrm{M}(11)$, and $\mathrm{C} 18: 1$ decreases from $33.0 \mu \mathrm{M}$ (11) to $11.61 \mu \mathrm{M}(9)$. In addition, levels of sphinganine and sphingosine increase with exercise. Sphinganine will 
increase in intramuscular concentration from about $1.6 \mu \mathrm{M}$ to $17.0 \mu \mathrm{M}$, and sphingosine will increase from about $3.0 \mu \mathrm{M}$ to $15.0 \mu \mathrm{M}(10)$.

\section{Hypothesis}

Given that exercise increases both AMPKK and P-AMPK protein abundance, AMPKK is likely more active with muscle excitation. However, current data show that this is not the case. It is hypothesized that the changes to the intracellular environment during contraction will activate AMPKK through allosteric mechanisms, thus giving an explanation for both the apparent drop in AMPKK activity and rise in AMPK phosphorylation during skeletal muscle exercise.

\section{Proposed Experiments}

1) AMPKK activity assays using recombinant LKB1/STRAD/MO25 and recombinant $\alpha 2 \beta 2 \gamma 2$-AMPK will be performed in the individual presence of either G6P, F6P, F1,6-P2, 3PG, G1P, G1,6-P2, ADP, carnitine, acetylcarnitine, inosine, IMP, ammonia, C16 ceramide, sphinganine, or sphingosine to test their effects at both resting and exercising concentrations.

2) Phospho-AMPK (P-AMPK) activity assays will be performed for those compounds that exhibit an effect on AMPKK activity. The results of this will show whether the activation or inhibition seen in Experiment 1 is affecting the AMPKK complex or AMPK. 
3) AMPKK activity assays will be performed using recombinant $\alpha 1 \beta 1 \gamma 1$-AMPK for the compounds that affect AMPKK activity. This will demonstrate whether the effect is specific to muscle tissue or not.

4) For the compounds used in Experiment 3, Western blots will be performed to give further evidence for its ability to alter AMPK phosphorylation via

\section{AMPKK.}

5) To elucidate whether the effects of the compounds used in Experiment 3 are experienced through allosteric mechanisms, further enzyme activity assays will be performed.

\section{Methods}

Buffers. When applicable, dithiothreitol (DTT) and $\left[\gamma^{32}\right]$ ATP are added just prior to use. AMPK Storage Buffer: $50 \mathrm{mM}$ Tris-HCl, $250 \mathrm{mM}$ Mannitol, $1 \mathrm{mM}$ EDTA, 1mM EGTA, $1 \mathrm{mM}$ DTT, 0.02\% (w/v) Brij-35, 10\% v/v glycerol, pH 7.4 at $4^{\circ} \mathrm{C}$. AMPK Phosphorylation Buffer: $100 \mathrm{mM}$ Hepes, $200 \mathrm{mM} \mathrm{NaCl}, 20 \%$ glycerol, 2 mM EDTA, $12.5 \mathrm{mM} \mathrm{MgCl}_{2}, 0.5 \mathrm{mM}$ AMP, $0.5 \mathrm{mM}$ ATP, 2.0 mM DTT, pH 7.0. AMARA Phosphorylation Buffer: $40 \mathrm{mM}$ Hepes, $80 \mathrm{mM} \mathrm{NaCl}, 8 \%$ glycerol, $0.8 \mathrm{mM}$ EDTA, $0.8 \mathrm{mM}$ DTT, $5 \mathrm{mM} \mathrm{MgCl} 2,0.2 \mathrm{mM}$ AMP, $0.2 \mathrm{mM}$ ATP, $0.33 \mathrm{mM}$ AMARA peptide, $0.05 \mu \mathrm{Ci} / \mu \mathrm{l}\left[\gamma^{32}\right] \mathrm{ATP}, \mathrm{pH}$ 7.0. Laemmli's Buffer: (34). PBS: $140 \mathrm{mM} \mathrm{NaCl}$, 2.7 mM KCl, $2.1 \mathrm{mM} \mathrm{KH}_{2} \mathrm{PO}_{4}, 9.9 \mathrm{mM} \mathrm{Na}_{2} \mathrm{HPO}_{4}, \mathrm{pH}$ 7.3. PBST: PBS with $1 \%$ Tween-20.

AMPKK Activity Assay. AMPKK activity is measured in a two-step assay. In the first step, AMPK is phosphorylated and activated by AMPKK. In the second step, 
P-AMPK phosphorylates AMARA peptide (21). Recombinant $\alpha 1 \beta 1 \gamma 1$ or $\alpha 2 \beta 2 \gamma 2$ AMPK was diluted 1:19 in water. Recombinant LKB1/STRAD/MO25 $(0.86 \mu \mathrm{g} / \mu \mathrm{l})$ is diluted 1:39 in AMPK storage buffer. The testing compounds, G6P, F6P, F1,6-P2, 3PG, G1P, G1,6-P2, ADP, carnitine, acetyl-carnitine, inosine, IMP, ammonia, C16 ceramide, sphingosine, and sphinganine are dissolved in water at five times the desired final concentration during the first step of the reaction. For the assay, $4 \mu 1$ of AMPK phosphorylation buffer is mixed with $2 \mu \mathrm{l}$ of diluted recombinant AMPK, $2 \mu 1$ of the testing compound, and $2 \mu \mathrm{l}$ of AMPKK and allowed to incubate for $20 \mathrm{~min}$ at $30^{\circ} \mathrm{C}$. After the incubation, $15 \mu \mathrm{l}$ of AMARA phosphorylation buffer is added to the mixture to start the second step of the assay and allowed to incubate for an additional $10 \mathrm{~min}$. At the conclusion of the $10 \mathrm{~min}$, the reaction is stopped by spotting on a $1 \mathrm{~cm}^{2}$ piece of Whatman P81 filter paper with $15 \mu \mathrm{l}$ of the final reaction mixture. Filter papers are allowed to absorb for $15 \mathrm{sec}$ and then placed in $100 \mathrm{ml}$ of $1 \%$ phosphoric acid. The papers are washed in the acid six times and then dried with a brief rinse of acetone. They are allowed to dry and then placed in $3 \mathrm{ml}$ of Ecolite scintillation fluid and counted for $1 \mathrm{~min}$.

P-AMPK Activity Assay. Same as the AMPKK activity assay, but with the testing compound being added during the second reaction instead of the first. To compensate for the addition at this step, $13 \mu \mathrm{l}$ of AMARA phosphorylation buffer is added, and all concentrations are adjusted to have equal final concentrations as in the AMPKK activity assay.

Western Blot. The first step of the AMPKK assay is performed. After the 20 min incubation period, the reaction is stopped by addition of diluted $4 \mathrm{x}$ Laemmli's 
buffer and water (1:1:2). The reaction mixtures are then separated by SDS-PAGE at $200 \mathrm{~V}$ for 35 minutes in $7.5 \%$ Tris-HCl, $50 \mu \mathrm{l}$ well Ready Gels. Proteins are transferred from the gels to nitrocellulose membranes at $100 \mathrm{~V}$ for $50 \mathrm{~min}$. Membranes are blocked in PBST and 5\% Blotting Grade Blocker Non-Fat Dry Milk for $1 \mathrm{~h}$. Membranes are incubated overnight at $4 \mathrm{C}$ in PBST, 5\% blocking milk, and first antibodies. After incubation with the first antibody, membranes are washed twice with PBST for 10 minutes and twice with PBS for 5 minutes. Membranes are then incubated for 1 hour at room temperature in PBST, 3\% blocking milk, and a second antibody. Following incubation with the second antibody, membranes are washed twice with PBST for 10 minutes and twice with PBS for 5 minutes. Membranes are covered with ECL Western Blotting Detection Reagent, enclosed in plastic wrap, and visualized on Hyperfilm ECL High Performance Chemiluminescence film. Relative amounts of protein are quantified by measuring spot size and intensity with AlphEaseFC Software. 


\section{References}

1. Baas AF, Boudeau J, Sapkota GP, Smit L, Medema R, Morrice NA, Alessi DR, and Clevers HC. Activation of the tumour suppressor kinase LKB1 by the STE20-like pseudokinase STRAD. EMBO J 22: 3062-3072, 2003.

2. Bergeron R, Russell RR 3rd, Young LH, Ren JM, Marcucci M, Lee A, Shulman GI. Effect of AMPK activation on muscle glucose metabolism in conscious rats. Am J Physiol 276: E938-E944, 1999.

3. Boudeau J, Baas AF, Deak M, Morrice NA, Kieloch A, Schutkowski M, Prescott AR, Clevers HC, Alessi DR. MO25alpha/beta interact with STRADalpha/beta enhancing their ability to bind, activate and localize LKB1 in the cytoplasm. EMBO J 22: 5102-5114, 2003.

4. Brindley DN, Wang CN, Mei J, Xu J, and Hanna AN. Tumor necrosis factoralpha and ceramides in insulin resistance. Lipids 34 Suppl: S85-S88, 1999.

5. Carling D, and Hardie DG. The substrate and sequence specificity of the AMP-activated protein kinase. Phosphorylation of glycogen synthase and phosphorylase kinase. Biochim Biophys Acta 1012: 81-86, 1989.

6. Cheung PC, Salt IP, Davies SP, Hardie DG, and Carling D. Characterization of AMP-activated protein kinase gamma-subunit isoforms and their role in AMP binding. Biochem J 346: 659-669, 2000.

7. Constantin-Teodosiu D, Simpson EJ, and Greenhaff PL. The importance of pyruvate availability to PDC activation and anaplerosis in human skeletal muscle. Am J Physiol 276: E472-E478, 1999. 
8. Corton JM, Gillespie JG, and Hardie DG. Role of the AMP-activated protein kinase in the cellular stress response. Curr Biol 4: 315-324, 1994.

9. Dobrzyn A, and Gorski J. Ceramides and sphingomyelins in skeletal muscles of the rat: content and composition. Effect of prolonged exercise. Am J Physiol Endocrinol Metab 282: E277-E285, 2002.

10. Dobrzyn A, and Gorski J. Effect of acute exercise on the content of free sphinganine and sphingosine in different skeletal muscle types of the rat. Horm Metab Res 34: 523-529, 2002.

11. Dobrzyn A, Zendzian-Piotrowska M, and Gorski J. Effect of endurance training on the sphingomyelin-signalling pathway activity in the skeletal muscles of the rat. J Physiol Pharmacol 55: 305-313, 2004.

12. Durante PE, Mustard KJ, Park SH, Winder WW, and Hardie DG. Effects of endurance training on activity and expression of AMP-activated protein kinase isoforms in rat muscles. Am J Physiol Endocrinol Metab 283: E178E186, 2002.

13. Esbjornsson-Liljedahl M, Bodin K, Jansson E. Smaller muscle ATP reduction in women than in men by repeated bouts of sprint exercise. J Appl Physiol 93: 1075-1083, 2001.

14. Feraudi M, Kolb J, Hassel M, and Weicker H. ATP-ADP-dependent phosphorylations of glycolysis metabolites, creatine and glycerol: their compartition and thermodynamic relationship in gastrocnemius muscle cell of exercised guinea pigs. Arch Int Physiol Biochim 91: 351-360, 1983. 
15. Fujii N, Hayashi T, Hirshman MF, Smith JT, Habinowski SA, Kaijser L, Mu J, Ljungqvist O, Birnbaum MJ, Witters LA, Thorell A, and Goodyear

LJ. Exercise induces isoform-specific increase in 5'AMP-activated protein kinase activity in human skeletal muscle. Biochem Biophys Res Commun 273: $1150-1155,2000$.

16. Goodyear LJ. AMP-activated protein kinase: a critical signaling intermediary for exercise-stimulated glucose transport? Exerc Sport Sci Rev 28: 113-116, 2000.

17. Goodyear LJ, and Kahn BB. Exercise, glucose transport, and insulin sensitivity. Annu Rev Med 49: 235-261, 1998.

18. Gorski J, Dobrzyn A, and Zendzian-Piotrowska M. The sphingomyelinsignaling pathway in skeletal muscles and its role in regulation of glucose uptake. Ann N Y Acad Sci 967: 236-248, 2002.

19. Hargreaves M, McKenna MJ, Jenkins DG, Warmington SA, Li JL, Snow RJ, and Febbraio MA. Muscle metabolites and performance during highintensity, intermittent exercise. J Appl Physiol 84: 1687-1691, 1998.

20. Hawley SA, Boudeau J, Reid JL, Mustard KJ, Udd L, Makela TP, Alessi DR, and Hardie DG. Complexes between the LKB1 tumor suppressor, STRAD alpha/beta and MO25 alpha/beta are upstream kinases in the AMPactivated protein kinase cascade. J Biol 2: 28, 2003.

21. Hawley SA, Davison M, Woods A, Davies SP, Beri RK, Carling D, and Hardie DG. Characterization of the AMP-activated protein kinase kinase from rat liver and identification of threonine 172 as the major site at which it 
phosphorylates AMP-activated protein kinase. J Biol Chem 271: 27879-27887, 1996.

22. Hayashi T, Hirshman MF, Kurth EJ, Winder WW, and Goodyear LJ. Evidence for 5' AMP-activated protein kinase mediation of the effect of muscle contraction on glucose transport. Diabetes 47: 1369-1373, 1998.

23. Hayashi T, Wojtaszewski JF, and Goodyear LJ. Exercise regulation of glucose transport in skeletal muscle. Am J Physiol 273: E1039-E1051, 1997.

24. Hellsten Y, Richter EA, Kiens B, and Bangsbo J. AMP deamination and purine exchange in human skeletal muscle during and after intense exercise. $J$ Physiol 520: 909-920, 1999.

25. Hemminki A, Markie D, Tomlinson I, Avizienyte E, Roth S, Loukola A, Bignell G, Warren W, Aminoff M, Hoglund P, Jarvinen H, Kristo P, Pelin K, Ridanpaa M, Salovaara R, Toro T, Bodmer W, Olschwang S, Olsen AS, Stratton MR, de la Chapelle A, and Aaltonen LA. A serine/threonine kinase gene defective in Peutz-Jeghers syndrome. Nature 391: 184-187, 1998.

26. Henin N, Vincent MF, and Van den Berghe G. Stimulation of rat liver AMPactivated protein kinase by AMP analogues. Biochim Biophys Acta 1290: 197203, 1996.

27. Hintz CS, Chi MM, Fell RD, Ivy JL, Kaiser KK, Lowry CV, and Lowry OH. Metabolite changes in individual rat muscle fibers during stimulation. Am J Physiol 242: C218-C228, 1982.

28. Holloszy JO, and Kohrt WM. Regulation of carbohydrate and fat metabolism during and after exercise. Annu Rev Nutr 16: 121-138, 1996. 
29. Hurst D, Taylor EB, Cline TD, Greenwood LJ, Compton CL, Lamb JD, and Winder WW. AMP-activated protein kinase kinase activity and phosphorylation of AMP-activated protein kinase in contracting muscle of sedentary and endurance-trained rats. Am J Physiol Endocrinol Metab 289: E710-E715, 2005.

30. Hutber CA, Hardie DG, and Winder WW. Electrical stimulation inactivates muscle acetyl-CoA carboxylase and increases AMP-activated protein kinase. Am J Physiol 272: E262-E266, 1997.

31. Hutber CA, Rasmussen BB, Winder WW. Endurance training attenuates the decrease in skeletal muscle malonyl-CoA with exercise. J Appl Physiol 83: 1917-1922, 1997.

32. Katz A, Sahlin K, and Broberg S. Regulation of glucose utilization in human skeletal muscle during moderate dynamic exercise. Am J Physiol 260: E411E415, 1991.

33. Kurth-Kraczek EJ, Hirshman MF, Goodyear LJ, and Winder WW. 5' AMP-activated protein kinase activation causes GLUT4 translocation in skeletal muscle. Diabetes 48: 1667-1671, 1999.

34. Laemmli UK. Cleavage of structural proteins during the assembly of the head of bacteriophatge T4. Nature 227: 680-685, 1970.

35. Merrill GF, Kurth EJ, Hardie DG, and Winder WW. AICA riboside increases AMP-activated protein kinase, fatty acid oxidation, and glucose uptake in rat muscle. Am J Physiol 273: E1107-E1112, 1997. 
36. Nielsen JN, Mustard KJ, Graham DA, Yu H, MacDonald CS, Pilegaard H, Goodyear LJ, Hardie DG, Richter EA, and Wojtaszewski JF. 5'-AMPactivated protein kinase activity and subunit expression in exercise-trained human skeletal muscle. J Appl Physiol 94: 631-641, 2003.

37. Putman CT, Jones NL, Hultman E, Hollidge-Horvat MG, Bonen A, McConachie DR, and Heigenhauser GJ. Effects of short-term submaximal training in humans on muscle metabolism in exercise. Am J Physiol 275: E132E139, 1998.

38. Rasmussen BB, and Winder WW. Effect of exercise intensity on skeletal muscle malonyl-CoA and acetyl-CoA carboxylase. J Appl Physiol 83: 11041109, 1997.

39. Sahlin K, Katz A, and Broberg S. Tricarboxylic acid cycle intermediates in human muscle during prolonged exercise. Am J Physiol 259: C834-C841, 1990.

40. Sakamoto K, Goransson O, Hardie DG, and Alessi DR. Activity of LKB1 and AMPK-related kinases in skeletal muscle: effects of contraction, phenformin, and AICAR. Am J Physiol Endocrinol Metab 287: E310-E317, 2004.

41. Sakamoto K, McCarthy A, Smith D, Green KA, Grahame Hardie D, Ashworth A, and Alessi DR. Deficiency of LKB1 in skeletal muscle prevents AMPK activation and glucose uptake during contraction. EMBO J 24: 1810$1820,2005$. 
42. Salmons S, Jarvis JC, Mayne CN, Chi MM, Manchester JK, McDougal DB Jr, and Lowry OH. Changes in ATP, phosphocreatine, and 16 metabolites in muscle stimulated for up to 96 hours. Am J Physiol 271: C1167-C1171, 1996.

43. Snow RJ, Carey MF, Stathis CG, Febbraio MA, and Hargreaves M. Effect of carbohydrate ingestion on ammonia metabolism during exercise in humans. $J$ Appl Physiol 88: 1576-1580, 2000.

44. Stapleton D, Mitchelhill KI, Gao G, Widmer J, Michell BJ, Teh T, House CM, Fernandez CS, Cox T, Witters LA, and Kemp BE. Mammalian AMPactivated protein kinase subfamily. J Biol Chem 271: 611-614, 1996.

45. Taylor EB, Ellingson WJ, Lamb JD, Chesser DG, and Winder WW. Longchain acyl-CoA esters inhibit phosphorylation of AMP-activated protein kinase at threonine-172 by LKB1/STRAD/MO25. Am J Physiol Endocrinol Metab 288: E1055-1061, 2005.

46. Taylor EB, Hurst D, Greenwood LJ, Lamb JD, Cline TD, Sudweeks SN, and Winder WW. Endurance training increases LKB1 and MO25 protein but not AMP-activated protein kinase kinase activity in skeletal muscle. Am J Physiol Endocrinol Metab 287: E1082-E1089, 2004.

47. Taylor EB, Lamb JD, Hurst RW, Chesser DG, Ellingson WJ, Greenwood LJ, Porter BB, Herway ST, and Winder WW. Endurance Training Increases Skeletal Muscle LKB1 and PGC-1 \{alpha\} Protein Abundance: Effects of Time and Intensity. Am J Physiol Endocrinol Metab 289: E960-E968, 2005. 
48. Thornton C, Snowden MA, and Carling D. Identification of a novel AMPKactivated protein kinase $\beta$ subunit isoform that is highly expressed in skeletal muscle. J Biol Chem 273: 12443-12450, 1998.

49. Turinsky J, O'Sullivan DM, and Bayly BP. 1,2-Diacylglycerol and ceramide levels in insulin-resistant tissues of the rat in vivo. J Biol Chem 265: 16880$16885,1990$.

50. van Loon LJ, Greenhaff PL, Constantin-Teodosiu D, Saris WH, and Wagenmakers AJ. The effects of increasing exercise intensity on muscle fuel utilization in humans. J Physiol 536: 295-304, 2001.

51. Vavvas D, Apazidis A, Saha AK, Gamble J, Patel A, Kemp BE, Witters LA, and Ruderman NB. Contraction-induced changes in acetyl-CoA carboxylase and 5'-AMP-activated kinase in skeletal muscle. J Biol Chem 272: 1325513261, 1997.

52. Wang CN, O'Brien L, and Brindley DN. Effects of cell-permeable ceramides and tumor necrosis factor-alpha on insulin signaling and glucose uptake in 3T3L1 adipocytes. Diabetes 47: 24-31, 1998.

53. Winder WW, and Duan C. Control of fructose 2,6-diphosphate in muscle of exercising fasted rats. Am J Physiol 262: E919-E924, 1992.

54. Winder WW, Fisher SR, Gygi SP, Mitchell JA, Ojuka E, and Weidman DA. Divergence of muscle and liver fructose 2,6-diphosphate in fasted exercising rats. Am J Physiol 260: E756-E761, 1991. 
55. Winder WW, and Hardie DG. Inactivation of acetyl-CoA carboxylase and activation of AMP-activated protein kinase in muscle during exercise. Am J Physiol 270: E299-E304, 1996.

56. Winder WW, Wilson HA, Hardie DG, Rasmussen BB, Hutber CA, Call GB, Clayton RD, Conley LM, Yoon S, and Zhou B. Phosphorylation of rat muscle acetyl-CoA carboxylase by AMP-activated protein kinase and protein kinase A. J Appl Physiol 82: 219-225, 1997.

57. Wojtaszewski JF, Nielsen P, Hansen BF, Richter EA, Kiens B. Isoformspecific and exercise intensity-dependent activation of 5'-AMP-activated protein kinase in human skeletal muscle. J Physiol 528:221-6, 2000.

58. Zarzeczny R, Brault JJ, Abraham KA, Hancock CR, and Terjung RL. Influence of ribose on adenine salvage after intense muscle contractions. J Appl Physiol 91: 1775-1781, 2001.

59. Zhao S, Snow RJ, Stathis CG, Febbraio MA, and Carey MF. Muscle adenine nucleotide metabolism during and in recovery from maximal exercise in humans. J Appl Physiol 88: 1513-1519, 2000. 
THE EFFECTS OF 3-PHOSPHOGLYCERATE AND OTHER METABOLITES ON ACTIVATION OF AMP-ACTIVATED PROTEIN KINASE BY LKB1-STRAD-MO25

\begin{abstract}
Skeletal muscle contraction results in the phosphorylation and activation of the AMPactivated protein kinase (AMPK) by an upstream kinase, AMPKK. The LKB1STRAD-MO25 complex is the major AMPKK in skeletal muscle; however, LKB1STRAD-MO25 activity is not increased by muscle contraction. This relationship suggests that phosphorylation of AMPK by LKB1-STRAD-MO25 during skeletal muscle contraction may be regulated by allosteric mechanisms. In this study we tested an array of metabolites including glucose-6-phosphate (G6P), fructose-6-phosphate (F6P), fructose 1,6-bisphosphate (F1,6- $\left.\mathrm{P}_{2}\right), 3$-phosphoglycerate (3PG), glucose-1phosphate (G1P), glucose-1,6-bisphosphate (G1,6- $\left.\mathrm{P}_{2}\right)$, adenosine diphosphate (ADP), carnitine (Carn), acetyl-carnitine (Acarn), inosine monophosphate (IMP), inosine, and ammonia for allosteric regulation. We found that 3PG stimulated LKB1-STRADMO25 activity and allowed for increased AMPK phosphorylation. 3PG did not stimulate LKB1-STRAD-MO25 activity toward the peptide substrate LKB1tide. These results have identified 3PG as an AMPK-specific regulator of AMPK phosphorylation and activation by LKB1-STRAD-MO25.
\end{abstract}

Key Words: AMPK; AMPKK; metabolism; glycolysis; STK11 


\section{INTRODUCTION}

The AMP-activated protein kinase (AMPK) is a master metabolic regulator found to regulate fatty acid oxidation $(20,43,44)$ and glucose uptake $(2,11,17,20)$ in skeletal muscle. AMPK senses changes in AMP-to-ATP ratios. An increase in AMP concentration causes a conformational change in AMPK. This occurs when 2 AMP molecules bind to 4 cystathione $\beta$-synthase (CBS) domains on the $\gamma$-subunit of AMPK $(1,31)$. This conformational change allows AMPK to be phosphorylated, and consequently activated, by an upstream kinase, AMPKK, composed of three complexed proteins, LKB1, STE-related adaptor (STRAD), and mouse protein 25 (MO25) $(9,32,45)$. AMPK must be phosphorylated by AMPKK on its activation loop at $\mathrm{Thr}^{172}$ for full activation.

AMPK is activated by the constitutively active kinase complex LKB1STRAD-MO25 during skeletal muscle contraction $(28,29)$. AMPK activation increases during a bout of skeletal muscle contraction caused by endurance exercise (41), in situ stimulation $(14,15,28,39)$, or in vitro stimulation $(11)$, while the apparent AMPKK activity does not change $(14,28)$. Furthermore, studies showing skeletal muscle contraction of both trained humans (21) and rats (14) yielded increases in AMPK phosphorylation in the face of no change or decreased measurable AMPKK activity. This relationship seems contradictory, given that one would expect an increased AMPKK activity to accompany the increased AMPK phosphorylation. These findings imply that muscle AMPKK becomes more active during contraction by mechanisms other than covalent modifications which could be detected in extracts of the muscle homogenate. Since LKB1-STRAD-MO25 can phosphorylate at least 14 
downstream kinases, substrate level regulation for each of these is conceivable.

Allosteric activation of AMPK phosphorylation by undefined modulators must also be considered as a mechanism of specific regulation of downstream targets.

To explore this issue, we considered changes that occur in the skeletal muscle metabolite concentrations during contraction. Previous studies have demonstrated exercise-induced changes in the concentrations of glucose-6-phosphate $(\mathrm{G} 6 \mathrm{P})(12,13$, 16, 26, 30), fructose-6-phosphate (F6P) (12, 26, 41, 42), fructose-1,6-bisphosphate $\left(\mathrm{F} 1,6-\mathrm{P}_{2}\right)(13,30,42), 3$-phosphoglycerate (3PG) (6), glucose-1-phosphate (G1P) (12), glucose-1,6-bisphosphate $\left(\mathrm{G} 1,6-\mathrm{P}_{2}\right)(30,41)$, adenosine diphosphate (ADP) $(12,26$, 33), carnitine (Carn) $(3,27,38)$, acetyl-carnitine (Acarn) $(3,27,38)$, inosine monophosphate (IMP) $(12,46,47)$, inosine $(5,8,47)$, and ammonia $(12,33)$. We hypothesized that one or more of these metabolites would demonstrate allosteric control on AMPK activation by interacting either directly on the LKB1-STRADMO25 complex, or on AMPK itself, making it a better substrate for phosphorylation by LKB1-STRAD-MO25.

\section{MATERIALS AND METHODS}

Buffers. When applicable, dithiothreitol (DTT) and $\left[\gamma^{32} \mathrm{P}\right] \mathrm{ATP}$ are added just prior to use. AMPK Storage Buffer: $50 \mathrm{mM}$ Tris-HCl, $250 \mathrm{mM}$ mannitol, $1 \mathrm{mM}$ EDTA, 1mM EGTA, 1 mM DTT, 0.02\% (w/v) Brij-35, 10\% v/v glycerol, pH 7.4 at $4^{\circ} \mathrm{C}$. AMPK Phosphorylation Buffer: $100 \mathrm{mM}$ Hepes, $200 \mathrm{mM} \mathrm{NaCl}, 20 \%$ glycerol, 2 mM EDTA, $12.5 \mathrm{mM} \mathrm{MgCl}_{2}, 0.5 \mathrm{mM}$ AMP, 0.5 mM ATP, 2.0 mM DTT, pH 7.0. AMARA Phosphorylation Buffer: $40 \mathrm{mM}$ Hepes, $80 \mathrm{mM} \mathrm{NaCl}$, 8\% glycerol, $0.8 \mathrm{mM}$ 
EDTA, $0.8 \mathrm{mM}$ DTT, $5 \mathrm{mM} \mathrm{MgCl} 2,0.2 \mathrm{mM}$ AMP, $0.2 \mathrm{mM}$ ATP, $0.33 \mathrm{mM}$ AMARA peptide, $0.05 \mu \mathrm{Ci} / \mu 1\left[\gamma^{32}\right] \mathrm{ATP}, \mathrm{pH}$ 7.0. Laemmli's Buffer: (18). PBS: $140 \mathrm{mM} \mathrm{NaCl}$, $2.7 \mathrm{mM} \mathrm{KCl}, 2.1 \mathrm{mM} \mathrm{KH} \mathrm{PO}_{4}, 9.9 \mathrm{mM} \mathrm{Na} 2 \mathrm{HPO}_{4}, \mathrm{pH}$ 7.3. PBST: PBS with $1 \%$ Tween-20.

Materials. General reagents were obtained from Sigma-Aldrich Chemical (St. Louis, MO) unless otherwise stated. G6P, F6P, F1,6- $\mathrm{P}_{2}$, 3PG, G1P, G1,6- $\mathrm{P}_{2}$, ADP, Carn, Acarn, IMP, and inosine were obtained from Sigma-Aldrich Chemical. Ammonium acetate was obtained from Merck KGaA (Darmstadt, Germany). Recombinant LKB1-STRAD-MO25 lot no. 28640AU (0.1 $\mu \mathrm{g} / \mu \mathrm{l}, 34 \mathrm{units} / \mathrm{mg})$ and LKB1tide were obtained from Upstate (Charleston, VA). His-bind nickel-binding resin was obtained from Novagen (Madison, WI). Western blotting primary antibodies were obtained from Cell Signaling Technologies (Danvers, MA). Resins for chromatographic purification, secondary antibody for Western blotting, and ECL detection solution were obtained from Amersham Biosciences (Piscataway, NJ).

Generation and Purification of Recombinant AMPK. Bacteria expressing recombinant $\alpha 2 \beta 2 \gamma 2$ and $\alpha 1 \beta 1 \gamma 1$ AMPK were prepared as previously described (22, $23,34,35)$. Recombinant $\alpha 2 \beta 2 \gamma 2$ and $\alpha 1 \beta 1 \gamma 1$ AMPK was extracted and purified by nickel affinity chromatography (36). After buffer exchange into AMPK storage buffer, recombinant AMPK was concentrated to $1 \mu \mathrm{g} / \mu \mathrm{l}$ before use for experimentation. Recombinant $\alpha-312$ AMPK protein for Western blot analysis was likewise obtained as previously described $(7,14,35,36)$.

AMPKK and P-AMPK Activity Assays. In all cases, unless otherwise stated, the AMPK used for experimentation was $\alpha 2 \beta 2 \gamma 2$ AMPK. AMPKK activity was 
measured in a two-step assay. In the first step, AMPK was phosphorylated and activated by LKB1-STRAD-MO25. In the second step, P-AMPK phosphorylated AMARA peptide (10). Recombinant $\alpha 2 \beta 2 \gamma 2$-AMPK was diluted 1:19 in water and $\alpha 1 \beta 1 \gamma 1$ was diluted 1:9 in water. Recombinant LKB1-STRAD-MO25 $(0.1 \mu \mathrm{g} / \mu \mathrm{l})$ was diluted 1:39 in AMPK storage buffer. The metabolites, G6P, F6P, F1,6P 2 , 3PG, G1P, G1,6 $\mathrm{P}_{2}$, ADP, Carn, Acarn, inosine, IMP, and ammonia were individually dissolved in water at $5 \mathrm{x}$ the desired final concentration before the first step of the reaction. G6P, F6P, ADP, and IMP were all controlled for their sodium content as previously described (34) and G1P was controlled for potassium in the same manner. For the assay, $4 \mu \mathrm{l}$ of AMPK phosphorylation buffer were mixed with $2 \mu \mathrm{l}$ of diluted recombinant AMPK, $2 \mu \mathrm{l}$ of the testing compound, and $2 \mu \mathrm{l}$ of AMPKK and allowed to incubate for $20 \mathrm{~min}$ at $30^{\circ} \mathrm{C}$. After the incubation, $15 \mu \mathrm{l}$ of $A M A R A$ phosphorylation buffer was added to the mixture to start the second step of the assay and allowed to incubate for an additional $10 \mathrm{~min}$ at $30^{\circ} \mathrm{C}$. At the conclusion of the 10 min, the reaction was stopped by spotting $15 \mu$ of the final reaction mixture on a $1 \mathrm{~cm}^{2}$ piece of Whatman P81 filter paper. Filter papers were allowed to absorb the reaction mix for $15 \mathrm{sec}$ and then were placed in $100 \mathrm{ml}$ of $1 \%$ phosphoric acid. The papers were washed in the acid six times and then briefly in acetone. After drying, the papers were then placed in $3 \mathrm{ml}$ of Ecolite scintillation fluid and radioactivity was determined in a liquid scintillation counter for $1 \mathrm{~min}$.

Assays to measure the effects of ADP and 3PG on P-AMPK were performed the same as the AMPKK activity assay with the following changes. $2 \mu 1$ of water were added before the start of the first reaction instead of 5x ADP or 3PG. The first 
reaction was allowed to proceed for 30 min to allow for full phosphorylation of AMPK. The ADP or 3PG was added at the start of the second reaction.

For assays to determine the activity of LKB1-STRAD-MO25 in phosphorylating LKB1tide, $450 \mu 1$ AMPK phosphorylation buffer, $225 \mu 1$ of $0.775 \mathrm{mM}$ LKB1tide in water, $135 \mu \mathrm{l}$ of water, and $4 \mu \mathrm{l}$ of $\left[\gamma^{32} \mathrm{P}\right] \mathrm{ATP}$ were combined and $18 \mu \mathrm{l}$ of this mixture were loaded together with $5 \mathrm{X} 3 \mathrm{PG}$ as above. The reaction was started with the addition of $2 \mu 1$ recombinant LKB1-STRAD-MO25 diluted 1:4 in AMPK storage buffer and stopped by spotting the reaction mixture onto filter papers and continuing as above.

Western Blot. The first step of the AMPKK assay was performed, but with a 30 min incubation. After the incubation period, the reaction was stopped by addition of diluted $4 \mathrm{x}$ Laemmli's buffer and water (1:1:2). Proteins in the reaction mixture were then separated by SDS-PAGE at $200 \mathrm{~V}$ for 50 minutes in $7.5 \%$ Tris-HCl, $30 \mu 1$ well, Criterion Precast Gels (Bio-Rad, Hercules CA). Proteins were electrophoretically transferred from the gels to PVDF membranes at $100 \mathrm{~V}$ for $60 \mathrm{~min}$. Membranes were blocked in PBST and 5\% Blotting Grade Blocker Non-Fat Dry Milk for 1 hour. Membranes were incubated overnight at $4^{\circ} \mathrm{C}$ in PBST, 5\% blocking milk, and primary antibody. After incubation with a rabbit anti-P-AMPK antibody, membranes were washed twice with PBST for 10 minutes and twice with PBS for 5 minutes. Membranes were then incubated for 1 hour at room temperature in PBST, 3\% blocking milk, and a secondary antibody. Following incubation with an HRPlinked anti-rabbit antibody, membranes were washed twice with PBST for 10 minutes and twice with PBS for 5 minutes. Membranes were covered with ECL Western 
Blotting Detection Reagent, enclosed in transparent plastic sheets, and visualized on Classic Blue Autoradiography film. Relative amounts of protein were quantified by measuring spot size and intensity with AlphaEaseFC software (Alpha Innotech Corporation, San Leandro CA).

Statistics. The effects of each metabolite on AMPKK activity, assays testing effects of ADP and 3PG on AMPKK and P-AMPK activity, assays of AMPKK activity against $\alpha 1 \beta 1 \gamma 1 \mathrm{AMPK}$ in the presence of 3PG, Western blot analysis of 3PG mediated AMPK and $\alpha-312$ AMPK activation, and AMPKK activity assays against LKB1tide were all compared by one-way ANOVA. Post hoc comparisons were performed using Fisher's least significant difference multiple comparison test. For Western blotting of the inhibitory effect of ADP on AMPK phosphorylation, and comparisons of $V_{\max }$ and $K_{0.5}$ of the substrate-activation curves, Student's $t$-tests were used to test for statistical significance. For all statistical tests, significance was set at $p$ $<0.05$. All statistical procedures were performed using the NCSS statistical program (Kaysville, UT). All data are reported as means \pm SE.

\section{RESULTS}

To test the hypothesis that an intracellular metabolite demonstrates allosteric control of the phosphorylation of AMPK, we assayed the AMPKK activity of LKB1STRAD-MO25 in the presence of each of the following compounds: G6P, F6P, F1,6P 2 , 3PG, G1P, G1,6P 2 , ADP, Carn, Acarn, inosine, IMP, and ammonia. Each metabolite was assayed at concentrations typical of resting conditions and exercising conditions (Fig. 1A-D, $n=5-6$ ). Resting concentrations for all metabolites except 
Carn were determined by taking the lowest values cited in the primary literature.

Likewise, exercising concentrations were determined by taking the highest values cited. Given that Carn concentrations decrease during exercise, the resting concentration was found by taking the highest value, and the exercising concentration was found by taking the lowest value found in the primary literature. Addition of $\mathrm{ADP}$ at both resting and exercising concentrations resulted in a marked inhibition of LKB1-STRAD-MO25 activity, while addition of Carn at the resting concentration resulted in slight inhibition of LKB1-STRAD-MO25 activity (Fig. 1B). Addition of 3PG at the exercising concentration resulted in an increase in LKB1-STRAD-MO25 activity (Fig. 1D). Addition of all other metabolites had no effect on LKB1-STRADMO25 activity.

Given that the AMPKK assay is a two-step assay, with the metabolite being added at the beginning of the first step, it is possible that ADP and 3PG exhibit their effects on P-AMPK rather than LKB1-STRAD-MO25. To test this, two assays were performed. The first was done the same as the previous assays, but with ADP at concentrations of $0,0.2,0.4,0.6,0.8$, and $1.0 \mathrm{mM}$. In the second assay, we fully phosphorylated AMPK and then added ADP at the same concentrations at the start of the second reaction. ADP had an inhibitory effect under both conditions, but the effect was greater in the first assay (Fig. 2A, $n=6$ ).

Because the P-AMPK assay showed ADP to inhibit P-AMPK activity, but demonstrated an inhibition of approximately $22 \%$ less than what was seen in the AMPKK assay, it was possible that ADP was inhibiting both P-AMPK and LKB1STRAD-MO25 activities. To test this, a Western blot was performed. We incubated 
LKB1-STRAD-MO25 with AMPK at ADP concentrations of 0 or $0.8 \mathrm{mM}$, stopped the reaction with Laemmli's buffer, and Western blotted for P-AMPK (Fig. 2B, $n=8$ ). Addition of $0.8 \mathrm{mM}$ ADP reduced P-AMPK quantities by approximately $22 \%$.

AMPKK and P-AMPK assays were also performed in the presence of $0,0.5$, 2.5, 5.0, 7.5, and 10.0 mM 3PG concentrations to test if it stimulates either LKB1STRAD-MO25 or P-AMPK activities. 3PG had a stimulatory effect on LKB1STRAD-MO25 activity, but no effect on P-AMPK activity (Fig. $3 A, n=5-6$ ). To validate the AMPKK assay by directly measuring the LKB1-STRAD-MO25 activity towards AMPK, Western blotting was performed. We incubated LKB1-STRADMO25 with AMPK at 3PG concentrations of $0,0.5,2.5,5.0,7.5$, and $10.0 \mathrm{mM}$, stopped the reaction with Laemmli's buffer, and Western blotted for P-AMPK. 3PG stimulated LKB1-STRAD-MO25 activity in the same pattern as was seen in the AMPKK activity assays (Fig. 3B, $n=7-8$ ). To test whether the stimulatory effect that 3PG has on LKB1-STRAD-MO25 is specific to the AMPK isoform used as a substrate, AMPKK assays were performed using $\alpha 1 \beta 1 \gamma 1$ AMPK at 3PG concentrations $0,0.5,2.5,5.0,7.5$, and $10.0 \mathrm{mM}$. 3PG was found to have a similar effect on $\alpha 1 \beta 1 \gamma 1$ AMPK activation, as it did on $\alpha 2 \beta 2 \gamma 2$ AMPK activation. Analysis was also performed on these blots to obtain a Hill coefficient, $V_{\max }$, and $K_{\mathrm{a}}$ (Fig. 4). The $V_{\max }$ was determined to be $157.0 \pm 12.4$ units, the $K_{\mathrm{a}}$ was found to be $1.50 \pm 0.28$ mM 3PG, and the Hill coefficient was found to be $1.49 \pm 0.26$. The best fit line was calculated using the average value at each data point.

To test whether 3PG is able to cause an LKB1-STRAD-MO25-mediated activation of a non-AMPK substrate, or whether 3PG has a substrate-specific 
stimulatory effect, we tested LKB1-STRAD-MO25 activity against the peptide substrate, LKB1tide at 3PG concentrations of 0 and $7.5 \mathrm{mM}$. Preliminary tests showed that 3PG had an inhibitory effect on LKB1-STRAD-MO25 activity towards LKB1tide. To ensure that the inhibitory effect was not caused by the sodium found in the $3 \mathrm{PG}$, additional assays were performed with sodium acetate at $15.0 \mathrm{mM}$. We found again that $3 \mathrm{PG}$ has an inhibitory effect, and that the inhibition is not due to the presence of sodium (Fig. 5, $n=6$ ).

We investigated the necessity of the $\beta$ and $\gamma$ - AMPK subunits in LKB1STRAD-MO25 activation of AMPK. Western blotting was done with LKB1STRAD-MO25 incubated with truncated $\alpha-312$ AMPK in the presence of $0.0,0.5,2.5$, 5.0, 7.5, and 10.0 mM 3PG. Analysis with anti-P-AMPK antibody detected a progressive increase in P-AMPK as a function of 3PG concentration, with a maximal increase of approximately 3 -fold seen at $5 \mathrm{mM}$ 3PG (Fig. 6, $n=8$ ).

Western blots were also done to investigate a possible allosteric interaction of 3PG. P-AMPK blots were performed at ATP concentrations of 0.0, 0.01, 0.025, 0.05, $0.1,0.2$, and $1.0 \mathrm{mM}$, and with or without $7.5 \mathrm{mM} 3 \mathrm{PG}$. Both 0.0 and $7.5 \mathrm{mM} 3 \mathrm{PG}$ curves demonstrated a sigmoidal curve. The $V_{\max }$ for LKB1-STRAD-MO25 in the absence of 3PG was $356 \pm 13.9$ relative units and the $K_{0.5}$ was $85.6 \pm 14.3 \mathrm{nM}$ ATP. The $V_{\max }$ for LKB1-STRAD-MO25 in the presence of $7.5 \mathrm{mM} 3 \mathrm{PG}$ was $468 \pm 23.2$ relative units and the $K_{0.5}$ was $55.8 \pm 5.36 \mathrm{nM}$ ATP (Fig. 7, $n=8$ ). 


\section{DISCUSSION}

Previous studies dealing with AMPKK activity and AMPK activation during exercise have produced data that appear to be contradictory. Previous studies have demonstrated a contraction-induced increase in phosphorylation of AMPK $(24,15,39$, 43) without concurrent detectable increases in AMPKK activity $(14,28)$. This discrepancy could be explained by the presence of intramuscular allosteric activators that increase in response to contraction. These activators would not be retained in the PEG precipitates utilized for determination of AMPKK activity. Very little is currently known about allosteric regulation of the LKB1-STRAD-MO25/AMPK system. Initial understanding of AMPK claimed that creatine phosphate $(\mathrm{CrP})$ acted as an allosteric inhibitor of $\operatorname{AMPK}(25,40)$; however, a recent study from our lab produced evidence against that concept (34). Another report from our lab demonstrated that long-chain acyl-CoA esters, such as palmitoyl-CoA, inhibit AMPKK activity, and that palmitoylcarnitine may act as an allosteric activator (35). In our current study we tested, in vitro, an array of metabolites at concentrations typical of both resting and exercising conditions in an attempt to discover an allosteric regulator.

From our first set of experiments, our data suggest that Carn, ADP, and 3PG all have some type of effect on LKB1-STRAD-MO25 activity (Fig. $1 B$ and $D$ ). We first investigated the drastic inhibition seen when LKB1-STRAD-MO25 and AMPK were incubated with ADP. Controlling for the presence of sodium in the ADP, both our AMPKK assay and our P-AMPK assay showed an ADP dose-dependent inhibition (Fig. 2A). Because in the AMPKK assay, the ADP was added at the beginning of the 
first step of the two-step assay and was still present during the second step, ADP could possibly be inhibiting P-AMPK, and not AMPKK. The P-AMPK assay showed a similar decrease in activity, which indicates that ADP is inhibiting the activity of PAMPK against its substrate, the AMARA peptide. However, there is a discrepancy in the extent that ADP caused inhibition between the AMPKK assay and the P-AMPK assay. At an ADP concentration of $0.8 \mathrm{mM}$, an approximately $22 \%$ difference is seen between the two assay curves. This difference could be explained by an inhibition of the LKB1-STRAD-MO25 complex as well. Western blot analysis confirmed that ADP indeed does inhibit the phosphorylation of AMPK by LKB1-STRAD-MO25 (Fig. 2B). We conclude that ADP is able to inhibit both P-AMPK, and to a lesser extent, LKB1-STRAD-MO25 activity towards AMPK.

Both our AMPKK assays and our Western blots clearly showed that 3PG acts as an activator of LKB1-STRAD-MO25 activity. Our P-AMPK assay also showed that 3PG has no significant effect on the activity of activated-AMPK. These results suggest that when an individual undergoes a bout of exercise, the change in the concentration of 3PG allows for the LKB1-STRAD-MO25 complex to more readily phosphorylate skeletal muscle AMPK. This effect, however, may not be isolated only to working skeletal muscle. Our AMPKK assay using $\alpha 1 \beta 1 \gamma 1$ AMPK as a substrate demonstrated a similar stimulatory response to increased 3PG levels (Fig. 3C). Given that very little information is available on the concentrations of 3PG during resting and exercising conditions in non-skeletal muscle sources, we can not declare with certainty that this new found effect will occur outside skeletal muscle, such as the liver; however, it does remain a possibility. 
Using the Western blot data from Figure 3B, a Hill coefficient was calculated. While recognizing Western blotting to represent a non-precise method of quantitation, a crude estimation of the activation constant $\left(K_{\mathrm{a}}\right)$ and Hill coefficient can be obtained. Though the method was crude, we were able to gain a general understanding from our analysis. Our calculated Hill coefficient of $1.49 \pm 0.26$ leads us to believe that $3 \mathrm{PG}$ exhibits mild cooperativity. Our calculated $K_{\mathrm{a}}$ for $3 \mathrm{PG}$ of $1.50 \pm 0.28$ lies well within the range of fluctuations in concentration expected to be observed between resting and contracting muscle.

We performed a number of experiments in an attempt to discern where 3PG was inducing its stimulatory effect. 3PG has the possibility of acting on either the LKB1-STRAD-MO25 complex, allowing it to phosphorylate AMPK better, or it could act on AMPK itself, causing AMPK to undergo a change, making it a better substrate for phosphorylation by the LKB1-STRAD-MO25 complex. Our evidence suggests that 3PG enhancement of LKB1-STRAD-MO25 activity is specific to AMPK as a substrate. AMPK is one of 14 kinases that have been found to be directly phosphorylated by LKB1 (19). The peptide LKB1tide corresponds to an amino acid sequence of another of the 14 kinases, NUAK2. LKB1-STRAD-MO25 activity against LKB1tide was inhibited by $7.5 \mathrm{mM} 3 \mathrm{PG}$, suggesting that the effect is specific to AMPK (Fig. 5). Likewise, AMPK phosphorylation was further enhanced when we used the truncated AMPK $\alpha-312$ subunit as shown by Western blot analysis. When we used the full $\alpha 2 \beta 2 \gamma 2$ AMPK as a substrate, maximal AMPK phosphorylation yielded an increase of approximately $160 \%$ (Fig. $3 B$ ), while the maximal increase in phosphorylation of the $\alpha-312$ AMPK reached nearly $300 \%$ (Fig. 6). These data 
suggest that 1) the $\beta$ and $\gamma$ AMPK subunits are not necessary for 3PG mediated enhancement of LKB1-STRAD-MO25 activity, and that 2) 3PG will either bind to the $\alpha$ AMPK subunit, or to the LKB1-STRAD-MO25 complex. In sum, while our data suggest that 3PG causes a substrate specific enhancement of LKB1-STRAD-MO25 activity, we can not definitively conclude that the effect was specific to AMPK. Further investigation of the effect of 3PG on multiple LKB1 substrates, as well as binding affinity experiments, would need to be performed in order to make such a conclusion. Furthermore, we were unable to conclude from our data where 3PG binding was occurring.

Regardless of the location of the 3PG binding, we present clear evidence as to the type of interaction that $3 \mathrm{PG}$ has with whichever enzyme it binds to (Fig. 7). First, we demonstrate the allosteric nature of ATP, in regards to the LKB1-STRAD-MO25 complex. The curve shown in Figure 7 clearly has a sigmoidal shape, which is consistent with allosteric enzymes. As well, we show that the maximal velocity of LKB1-STRAD-MO25 is reached at no more than $1.0 \mathrm{mM}$ ATP. Preliminary tests showed that incubation with concentrations of 2.0 and $4.0 \mathrm{mM}$ ATP yielded velocities which were not significantly different than at $1.0 \mathrm{mM}$ ATP (data not shown). LKB1STRAD-MO25 without any additional modulators was able to reach a $V_{\max }$ of $356 \pm$ 13.9 relative units, with a $K_{0.5}$ of $85.6 \pm 14.3 \mathrm{nM}$ ATP. At a $3 \mathrm{PG}$ concentration of 7.5 $\mathrm{mM}$, and with the same increasing concentrations of ATP, a sigmoidal curve was also observed. The $V_{\max }$ of this curve was $468 \pm 23.2$ relative units, with a $K_{0.5}$ of $55.8 \pm$ $5.36 \mathrm{nM}$ ATP. Comparing the two curves, the $V_{\max }$ of each curve is significantly different than the other, while the $K_{0.5}$ of each curve is not significantly different than 
the other. These results are consistent with allosteric activators; we believe that the data presented are sufficient to conclude that 3PG is an allosteric modulator of LKB1STRAD-MO25 activity.

We now propose a physiologic rationale for having $3 \mathrm{PG}$ as an activator of the AMPK pathway. 3PG could be acting as an energy utilization switch. At the onset of exercise, the predominant energy substrate used in skeletal muscle is glycogen. This glycogen is broken down to G6P, which then enters glycolysis. Further down the glycolytic pathway, 3PG will be formed. As more glycogen is continually broken down in the first moments of exercise, 3PG levels will continue to increase and will stimulate LKB1-STRAD-MO25 activity. This increase in LKB1-STRAD-MO25 activity will then activate AMPK and allow for blood glucose to be transported into the muscle. As exercise continues, the 3PG-induced elevation in AMPK activity will cause phosphorylation and inactivation of ACC, causing malonyl-CoA to decrease and allowing an increase in fatty acid oxidation as fatty acids become available. In short, this model suggests that $3 \mathrm{PG}$ contributes to AMPK activation, acting as a switch to turn on blood glucose utilization near the beginning of exercise, and allowing for more fatty acids to be oxidized as exercise continues over time.

In summary, we found that a majority of the metabolites that we investigated had no effect on LKB1-STRAD-MO25 activity. ADP had a partial inhibitory effect on LKB1-STRAD-MO25 activity, but a more pronounced effect on P-AMPK activity. Carnitine had an effect on LKB1-STRAD-MO25 while 3PG had a larger effect. While it seems clear that 3PG is an allosteric modulator of LKB1-STRAD-MO25 activity, we are unsure whether its effect is on the LKB1-STRAD-MO25 complex, or 
whether the effect occurs within the first 312 residues of the $\alpha$-AMPK subunit. Physiologically, 3PG may act as an energy substrate utilization sensor, or in some other capacity. Regardless, the discovery of an LKB1-STRAD-MO25 allosteric modulator appears to clarify why previous studies have shown contradictory evidence of exercise-induced decreases in AMPKK activity along with increased AMPK phosphorylation, and is generally important as we continue to learn and understand the AMPK signaling cascade. 


\section{REFERENCES}

1. Adams J, Chen ZP, Van Denderen BJ, Morton CJ, Parker MW, Witters LA, Stapleton D, and Kemp BE. Intrasteric control of AMPK via the gamma1 subunit AMP allosteric regulatory site. Protein Sci 13: 155-165, 2004.

2. Bergeron R, Russell RR 3rd, Young LH, Ren JM, Marcucci M, Lee A, and Shulman GI. Effect of AMPK activation on muscle glucose metabolism in conscious rats. Am J Physiol 276: E938-E944, 1999.

3. Constantin-Teodosiu D, Simpson EJ, and Greenhaff PL. The importance of pyruvate availability to PDC activation and anaplerosis in human skeletal muscle. Am J Physiol 276:E472-E478, 1999.

4. Durante PE, Mustard KJ, Park SH, Winder WW, and Hardie DG. Effects of endurance training on activity and expression of AMP-activated protein kinase isoforms in rat muscles. Am J Physiol Endocrinol Metab 283: E178E186, 2002.

5. Esbjornsson-Liljedahl M, Bodin K, and Jansson E. Smaller muscle ATP reduction in women than in men by repeated bouts of sprint exercise. J Appl Physiol 93: 1075-1083, 2001.

6. Feraudi M, Kolb J, Hassel M, and Weicker H. ATP-ADP-dependent phosphorylations of glycolysis metabolites, creatine and glycerol: their compartition and thermodynamic relationship in gastrocnemius muscle cell of exercised guinea pigs. Arch Int Physiol Biochim 91: 351-360, 1983. 
7. Hamilton SR, O'Donnell JB Jr, Hammet A, Stapleton D, Habinowski SA, Means AR, Kemp BE, Witters LA. AMP-activated protein kinase kinase: detection with recombinant AMPK alpha1 subunit. Biochem Biophys Res Commun 293: 892-898, 2002.

8. Hargreaves M, McKenna MJ, Jenkins DG, Warmington SA, Li JL, Snow RJ, and Febbraio MA. Muscle metabolites and performance during highintensity, Intermittent exercise. J Appl Physiol 84: 1687-1691, 1998.

9. Hawley SA, Boudeau J, Reid JL, Mustard KJ, Udd L, Makela TP, Alessi DR, and Hardie DG. Complexes between the LKB1 tumor suppressor, STRAD alpha/beta and MO25 alpha/beta are upstream kinases in the AMPactivated protein kinase cascade. J Biol 2: 28, 2003.

10. Hawley SA, Davison M, Woods A, Davies SP, Beri RK, Carling D, and Hardie DG. Characterization of the AMP-activated protein kinase kinase from rat liver and identification of threonine 172 as the major site at which it phosphorylates AMP-activated protein kinase. J Biol Chem 271: 27879-27887, 1996.

11. Hayashi T, Hirshman MF, Kurth EJ, Winder WW, and Goodyear LJ. Evidence for 5' AMP-activated protein kinase mediation of the effect of muscle contraction on glucose transport. Diabetes 47: 1369-1373, 1998.

12. Hellsten Y, Richter EA, Kiens B, and Bangsbo J. AMP deamination and purine exchange in human skeletal muscle during and after intense exercise. $J$ Physiol 520: 909-920, 1999. 


\section{Hintz CS, Chi MM, Fell RD, Ivy JL, Kaiser KK, Lowry CV, and Lowry}

OH. Metabolite changes in individual rat muscle fibers during stimulation. Am J Physiol 242: C218-C228, 1982.

14. Hurst D, Taylor EB, Cline TD, Greenwood LJ, Compton CL, Lamb JD, and Winder WW. AMP-activated protein kinase kinase activity and phosphorylation of AMP-activated protein kinase in contracting muscle of sedentary and endurance-trained rats. Am J Physiol Endocrinol Metab 289: E710-E715, 2005.

15. Hutber CA, Hardie DG, and Winder WW. Electrical stimulation inactivates muscle acetyl-CoA carboxylase and increases AMP-activated protein kinase. Am J Physiol 272: E262-E266, 1997.

16. Katz A, Sahlin K, and Broberg S. Regulation of glucose utilization in human skeletal muscle during moderate dynamic exercise. Am J Physiol 260: E411E415, 1991.

17. Kurth-Kraczek EJ, Hirshman MF, Goodyear LJ, and Winder WW. 5' AMP-activated protein kinase activation causes GLUT4 translocation in skeletal muscle. Diabetes 48: 1667-1671, 1999.

18. Laemmli UK. Cleavage of structural proteins during the assembly of the head of bacteriophatge T4. Nature 227: 680-685, 1970.

19. Lizcano JM, Goransson O, Toth R, Deak M, Morrice NA, Boudeau J, Hawley SA, Udd L, Makela TP, Hardie DG, and Alessi DR. LKB1 is a master kinase that activates 13 kinases of the AMPK subfamily, including MARK/PAR-1. EMBO J 23: 833-843, 2004. 
20. Merrill GF, Kurth EJ, Hardie DG, and Winder WW. AICA riboside increases AMP-activated protein kinase, fatty acid oxidation, and glucose uptake in rat muscle. Am J Physiol 273: E1107-E1112, 1997.

21. Nielsen JN, Mustard KJ, Graham DA, Yu H, MacDonald CS, Pilegaard H, Goodyear LJ, Hardie DG, Richter EA, and Wojtaszewski JF. 5'-AMPactivated protein kinase activity and subunit expression in exercise-trained human skeletal muscle. J Appl Physiol 94: 631-641, 2003.

22. Neumann D, Schlattner U, and Wallimann T. A molecular approach to the concerted action of kinases involved in energy homoeostasis. Biochem Soc Trans 31: 169-174, 2003.

23. Neumann D, Woods A, Carling D, Wallimann T, and Schlattner U. Mammalian AMP-activated protein kinase: functional, heterotrimeric complexes by co-expression of subunits in Escherichia coli. Protein Expr Purif 30: 230-237, 2003.

24. Park SH, Gammon SR, Knippers JD, Paulsen SR, Rubink DS, and Winder WW. Phosphorylation-activity relationships of AMPK and acetyl-CoA carboxylase in muscle. J Appl Physiol 92: 2475-2482, 2002.

25. Ponticos M, Lu QL, Morgan JE, Hardie DG, Partridge TA, and Carling D. Dual regulation of the AMP-activated protein kinase provides a novel mechanism for the control of creatine kinase in skeletal muscle. EMBO J 17: 1688-1699, 1998.

26. Putman CT, Jones NL, Hultman E, Hollidge-Horvat MG, Bonen A, McConachie DR, and Heigenhauser GJ. Effects of short-term submaximal 
training in humans on muscle metabolism in exercise. Am J Physiol 275: E132E139, 1998.

27. Sahlin K, Katz A, and Broberg S. Tricarboxylic acid cycle intermediates in human muscle during prolonged exercise. Am J Physiol 259: C834-C841, 1990.

28. Sakamoto K, Goransson O, Hardie DG, and Alessi DR. Activity of LKB1 and AMPK-related kinases in skeletal muscle: effects of contraction, phenformin, and AICAR. Am J Physiol Endocrinol Metab 287: E310-E317, 2004.

29. Sakamoto K, McCarthy A, Smith D, Green KA, Grahame Hardie D, Ashworth A, and Alessi DR. Deficiency of LKB1 in skeletal muscle prevents AMPK activation and glucose uptake during contraction. EMBO J 24: 1810$1820,2005$.

30. Salmons S, Jarvis JC, Mayne CN, Chi MM, Manchester JK, McDougal DB Jr, and Lowry OH. Changes in ATP, phosphocreatine, and 16 metabolites in muscle stimulated for up to 96 hours. Am J Physiol 271: C1167-C1171, 1996.

31. Scott JW, Hawley SA, Green KA, Anis M, Stewart G, Scullion GA, Norman DG, and Hardie DG. CBS domains form energy-sensing modules whose binding of adenosine ligands is disrupted by disease mutations. J Clin Invest 113: 274-284, 2004.

32. Shaw RJ, Kosmatka M, Bardeesy N, Hurley RL, Witters LA, DePinho RA, and Cantley LC. The tumor suppressor LKB1 kinase directly activates AMPactivated kinase and regulates apoptosis in response to energy stress. Proc Natl Acad Sci USA 101: 3329-3335, 2004. 
33. Snow RJ, Carey MF, Stathis CG, Febbraio MA, and Hargreaves M. Effect of carbohydrate ingestion on ammonia metabolism during exercise in humans. $J$ Appl Physiol 88: 1576-1580, 2000.

34. Taylor EB, Ellingson WJ, Lamb JD, Chesser DG, Compton CL, and Winder WW. Evidence against regulation of AMP-activated protein kinase and LKB1/STRAD/MO25 activity by creatine phosphate. Am J Physiol Endocrinol Metab 290: E661-E669, 2006.

35. Taylor EB, Ellingson WJ, Lamb JD, Chesser DG, and Winder WW. Longchain acyl-CoA esters inhibit phosphorylation of AMP-activated protein kinase at threonine-172 by LKB1/STRAD/MO25. Am J Physiol Endocrinol Metab 288: E1055-E1061, 2005.

36. Taylor EB, Hurst D, Greenwood LJ, Lamb JD, Cline TD, Sudweeks SN, and Winder WW. Endurance training increases LKB1 and MO25 protein but not AMP-activated protein kinase kinase activity in skeletal muscle. Am J Physiol Endocrinol Metab 287: E1082-E1089, 2004.

37. Taylor EB, Lamb JD, Hurst RW, Chesser DG, Ellingson WJ, Greenwood LJ, Porter BB, Herway ST, and Winder WW. Endurance Training Increases Skeletal Muscle LKB1 and PGC-1 \{alpha\} Protein Abundance: Effects of Time and Intensity. Am J Physiol Endocrinol Metab 289: E960-E968, 2005.

38. van Loon LJ, Greenhaff PL, Constantin-Teodosiu D, Saris WH, and Wagenmakers AJ. The effects of increasing exercise intensity on muscle fuel utilization in humans. J Physiol 536: 295-304, 2001. 
39. Vavvas D, Apazidis A, Saha AK, Gamble J, Patel A, Kemp BE, Witters LA, and Ruderman NB. Contraction-induced changes in acetyl-CoA carboxylase and 5'-AMP-activated kinase in skeletal muscle. J Biol Chem 272: 13255$13261,1997$.

40. Winder WW. AMP-activated protein kinase: possible target for treatment of type 2 diabetes. Diabetes Technol Ther 2: 441-448, 2000.

41. Winder WW, and Duan C. Control of fructose 2,6-diphosphate in muscle of exercising fasted rats. Am J Physiol 262: E919-E924, 1992.

42. Winder WW, Fisher SR, Gygi SP, Mitchell JA, Ojuka E, and Weidman DA. Divergence of muscle and liver fructose 2,6-diphosphate in fasted exercising rats. Am J Physiol 260: E756-E761, 1991.

43. Winder WW, and Hardie DG. Inactivation of acetyl-CoA carboxylase and activation of AMP-activated protein kinase in muscle during exercise. Am $J$ Physiol 270:E299-E304, 1996.

44. Winder WW, Wilson HA, Hardie DG, Rasmussen BB, Hutber CA, Call GB, Clayton RD, Conley LM, Yoon S, and Zhou B. Phosphorylation of rat muscle acetylCoA carboxylase by AMP-activated protein kinase and protein kinase A. J Appl Physiol $82: 219-225,1997$.

45. Woods A, Johnstone SR, Dickerson K, Leiper FC, Fryer LG, Neumann D, Schlattner U, Wallimann T, Carlson M, and Carling D. LKB1 is the upstream kinase in the AMP-activated protein kinase cascade. Curr Biol 13: 2004-2008, 2003. 
46. Zarzeczny R, Brault JJ, Abraham KA, Hancock CR, and Terjung RL. Influence of ribose on adenine salvage after intense muscle contractions. J Appl Physiol 91: 1775$1781,2001$.

47. Zhao S, Snow RJ, Stathis CG, Febbraio MA, and Carey MF. Muscle adenine nucleotide metabolism during and in recovery from maximal exercise in humans. $J$ Appl Physiol 88: 1513-1519, 2000. 


\section{FIGURE LEGENDS}

Figure 1. AMPKK activities of LKB1-STRAD-MO25 against AMPK in the presence of various metabolites at concentrations typical of resting and exercising values. (A) inosine: $0.005 \mathrm{mM}, 0.25 \mathrm{mM}$; IMP: $0.5 \mathrm{mM}, 5.0 \mathrm{mM}$; ammonia: $0.05 \mathrm{mM}, 0.5 \mathrm{mM}$. (B) Carn: $3.5 \mathrm{mM}, 1.0 \mathrm{mM}$; Acarn: $0.5 \mathrm{mM}, 5.0 \mathrm{mM}$; ADP $0.4 \mathrm{mM}, 0.8 \mathrm{mM}$. (C) G6P: 0.05 mM, 2.0 mM; G1P: $0.1 \mathrm{mM}, 0.4 \mathrm{mM}$; G1,6P2: $0.075 \mathrm{mM}, 0.5 \mathrm{mM}$. (D) F6P: $0.02 \mathrm{mM}, 0.15 \mathrm{mM}$; F1,6P2: $0.04 \mathrm{mM}, 0.2 \mathrm{mM}$; 3PG: $0.5 \mathrm{mM}, 1.5 \mathrm{mM}$. Concentrations of each metabolite are listed in the order of resting concentration, then exercising concentration. *Activity at these concentrations was significantly different from the respective $0 \mathrm{mM}$ concentration $(n=5-6, p<0.05)$.

Figure 2. Inhibition of AMPKK activity of LKB1-STRAD-MO25 and P-AMPK activity by ADP. (A) Assays of both AMPKK activity and P-AMPK activity in the presence of $0.0,0.2,0.4,0.6,0.8$, or $1.0 \mathrm{mM}$ ADP. (B) Measurement of ADP inhibition of LKB1-STRAD-MO25 by Western blot analysis of P-AMPK. LKB1STRAD-MO25 and AMPK were incubated in the presence of 0.0 or $0.8 \mathrm{mM}$ ADP.

All control values were normalized to 1. †Significantly different than AMPKK assay $(p<0.05)$. *Denotes a significant difference from the control $(n=5-8, p<0.05)$.

Figure 3. Stimulatory effect of 3PG on AMPKK activity of LKB1-STRAD-MO25 mediated AMPK activation. Concentrations of 3PG used in all experiments were 0.0 , 0.5, 2.5, 5.0, 7.5 and $10.0 \mathrm{mM}$. (A) Assays of both AMPKK activity and P-AMPK 
activity in the presence of 3PG. (B) Western blot validation of the stimulatory effect of 3PG on AMPKK activity. (C) Stimulation of AMPKK activity by 3 PG is not confined to muscle-specific AMPK. AMPKK assay was performed using $\alpha 1 \beta 1 \gamma 1$ AMPK as a substrate. Control values were normalized to 1 . †Significantly different than P-AMPK assay $(p<0.05)$. *Significant difference from control was observed at these concentrations $(n=5-8, p<0.05)$

Figure 4. Hill equation analysis of the effects of $3 \mathrm{PG}$ on AMPK phosphorylation. $V_{\max }=157.0 \pm 12.4, K_{\mathrm{a}}=1.5 \pm 0.28$, Hill coefficient $=1.49 \pm 0.26$. Data points were calculated using data from Western blots of Figure $3 B$. The line of best fit was determined using the Grafit Program from the increases in activity above the $0 \mathrm{mM}$ 3PG group.

Figure 5. AMPKK activity of LKB1-STRAD-MO25 in phosphorylating LKB1tide in the presence of $7.5 \mathrm{mM} 3 \mathrm{PG}$ and $15.0 \mathrm{mM}$ sodium acetate (SA). SA was used to verify that the observed inhibition was not due to the sodium content of 3PG. Control values normalized to 1 . * Significantly different from control $(n=6, p<0.05)$.

Figure 6. Activation of truncated AMPK ( $\alpha-312)$ by LKB1-STRAD-MO25 in the presence of $0.0,0.5,2.5,5.0,7.5$, and $10.0 \mathrm{mM} 3 \mathrm{PG}$. Control was normalized to 1 . *Significantly different than control $(n=8, p<0.05)$. 
Figure 7. Substrate-activity curves for LKB1-STRAD-MO25 activity against AMPK. ATP was the substrate used at concentrations of $0.0,0.01,0.025,0.05,0.1,0.2$, and 1.0 mM. 0.0 or $7.5 \mathrm{mM} 3 \mathrm{PG}$ were used to demonstrate $3 \mathrm{PG}$ as a positive allosteric modulator. For $0.0 \mathrm{mM} 3 \mathrm{PG}$ curve, the $V_{\max }$ was $356 \pm 13.9$, and $K_{0.5}$ was $85.6 \pm 14.3$ nM ATP. For $7.5 \mathrm{mM} 3 \mathrm{PG}$ curve, the $V_{\max }$ was $468 \pm 13.9$, and $K_{0.5}$ was $55.8 \pm 5.36$ nM ATP. $V_{\max }$ for the curves were significantly different while the $K_{0.5}$ for the curves was not. Significance was established as $p<0.05, n=8$. 
Figure 1
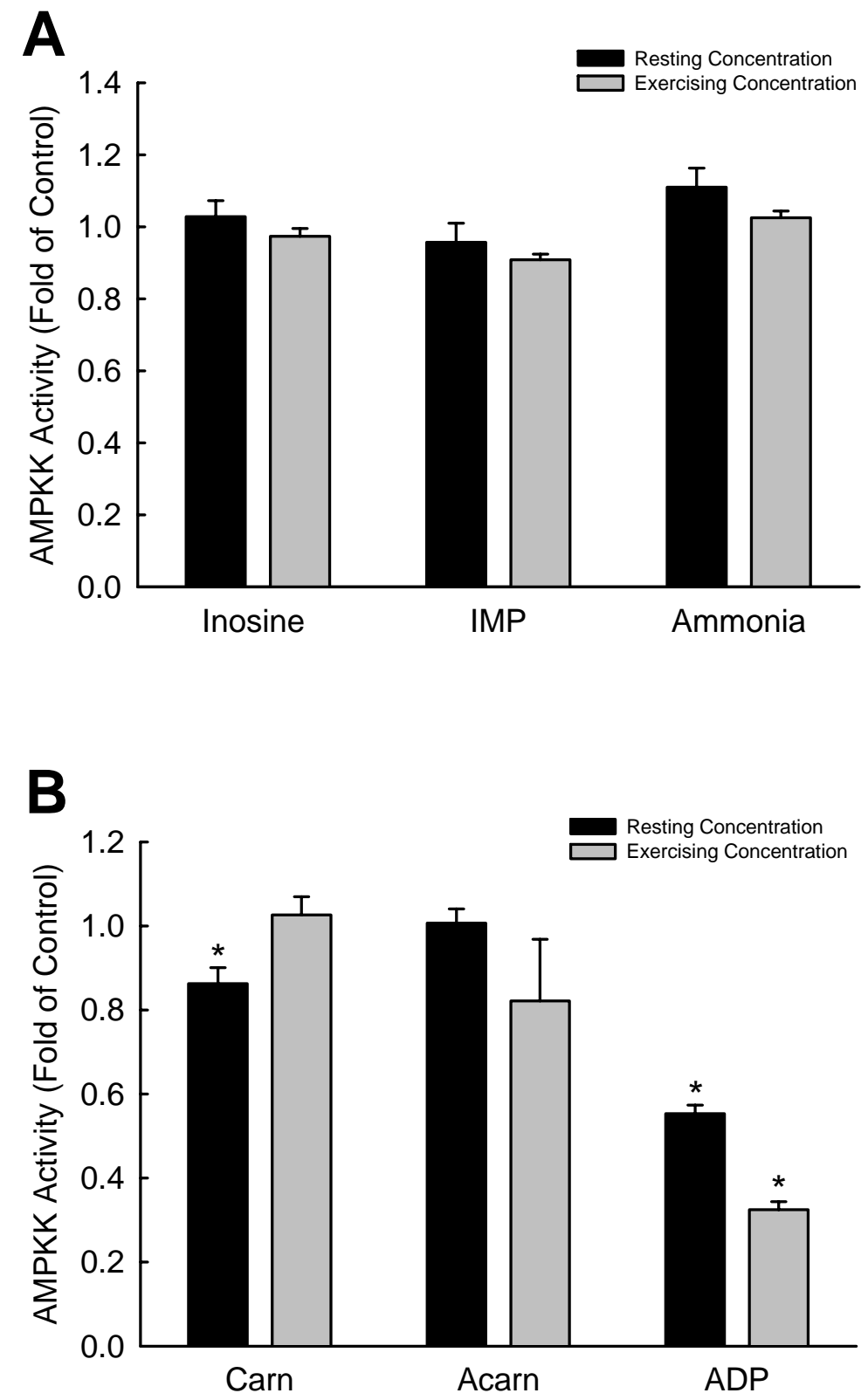
Figure 1
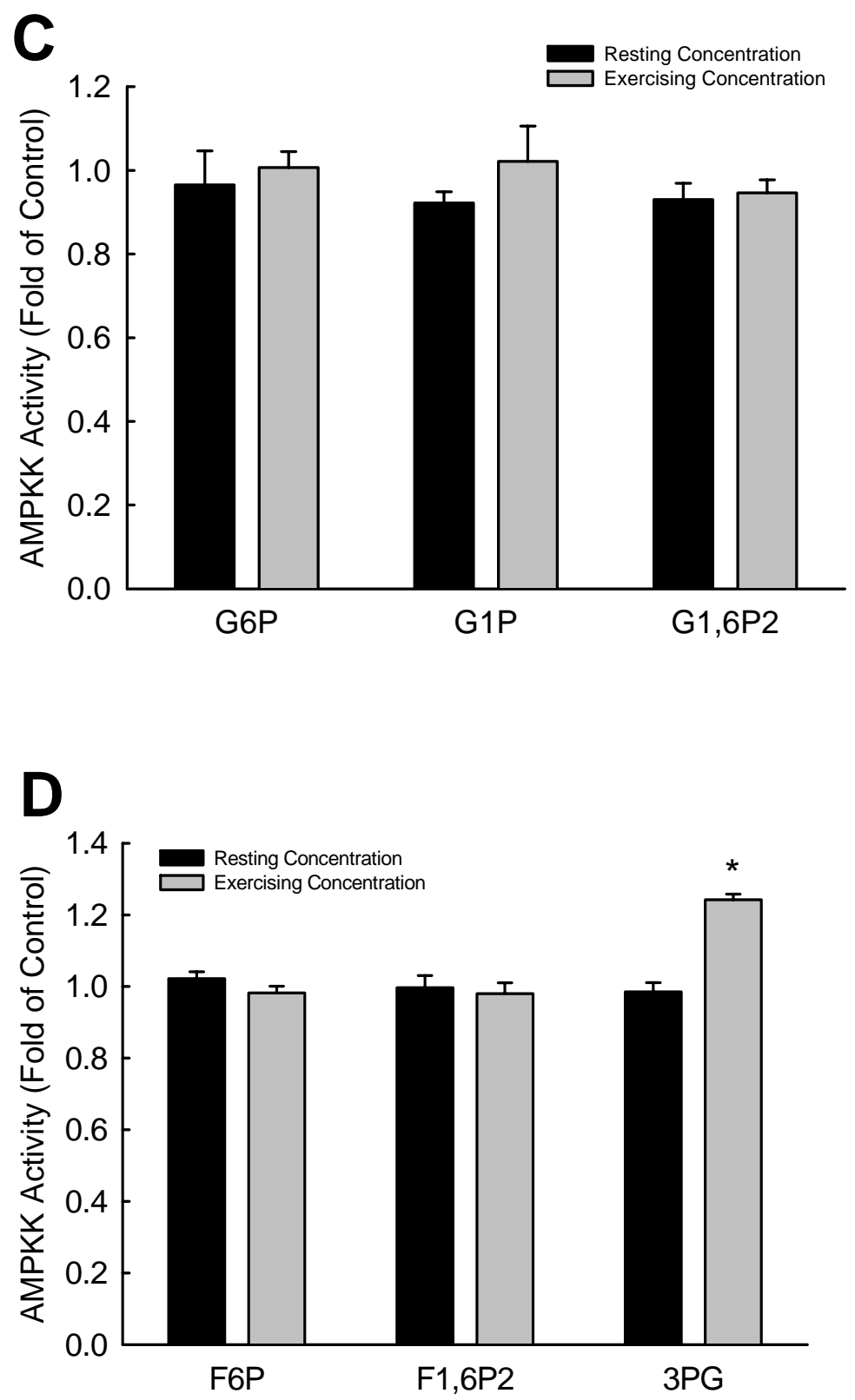
Figure 2

A
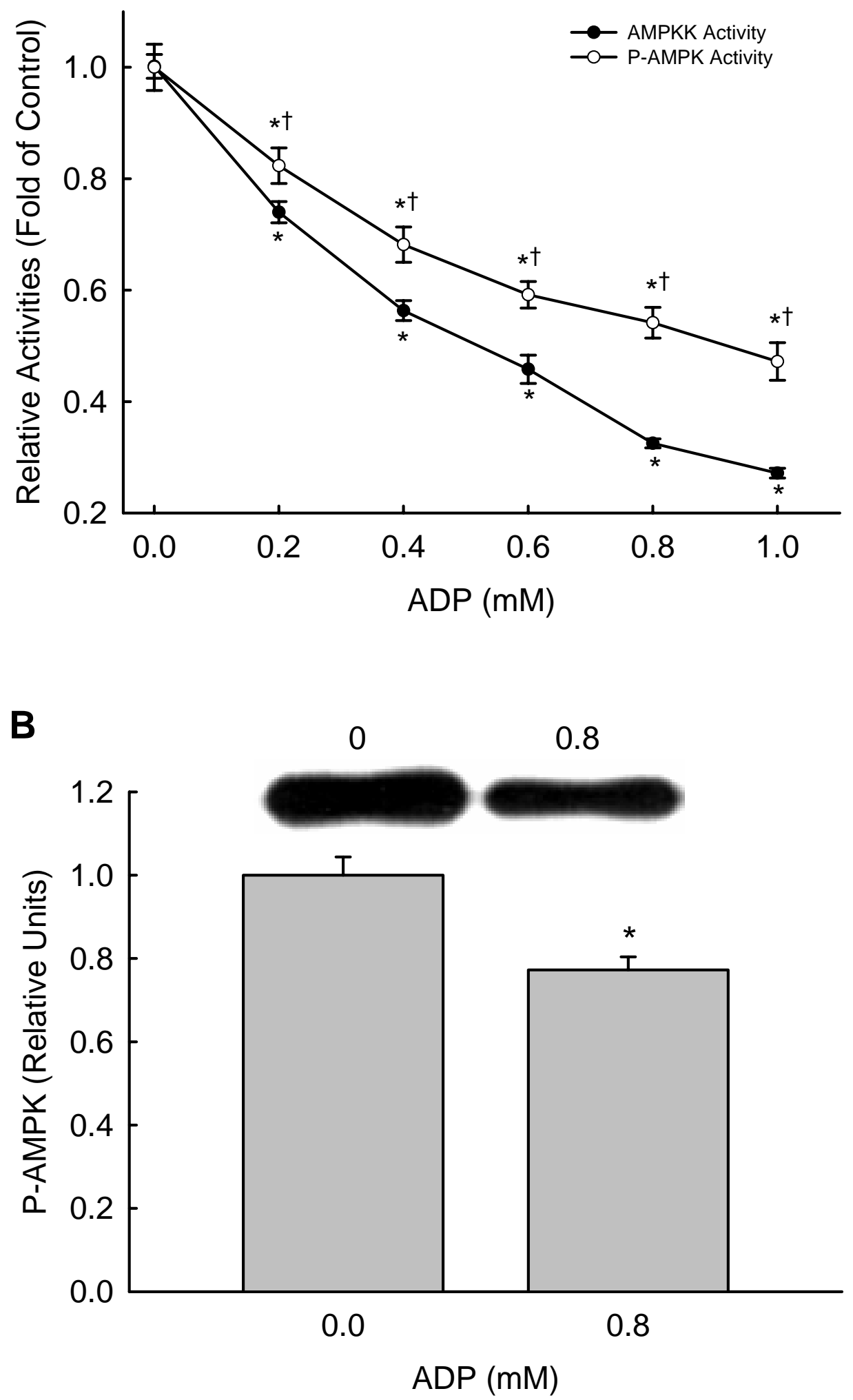
Figure 3
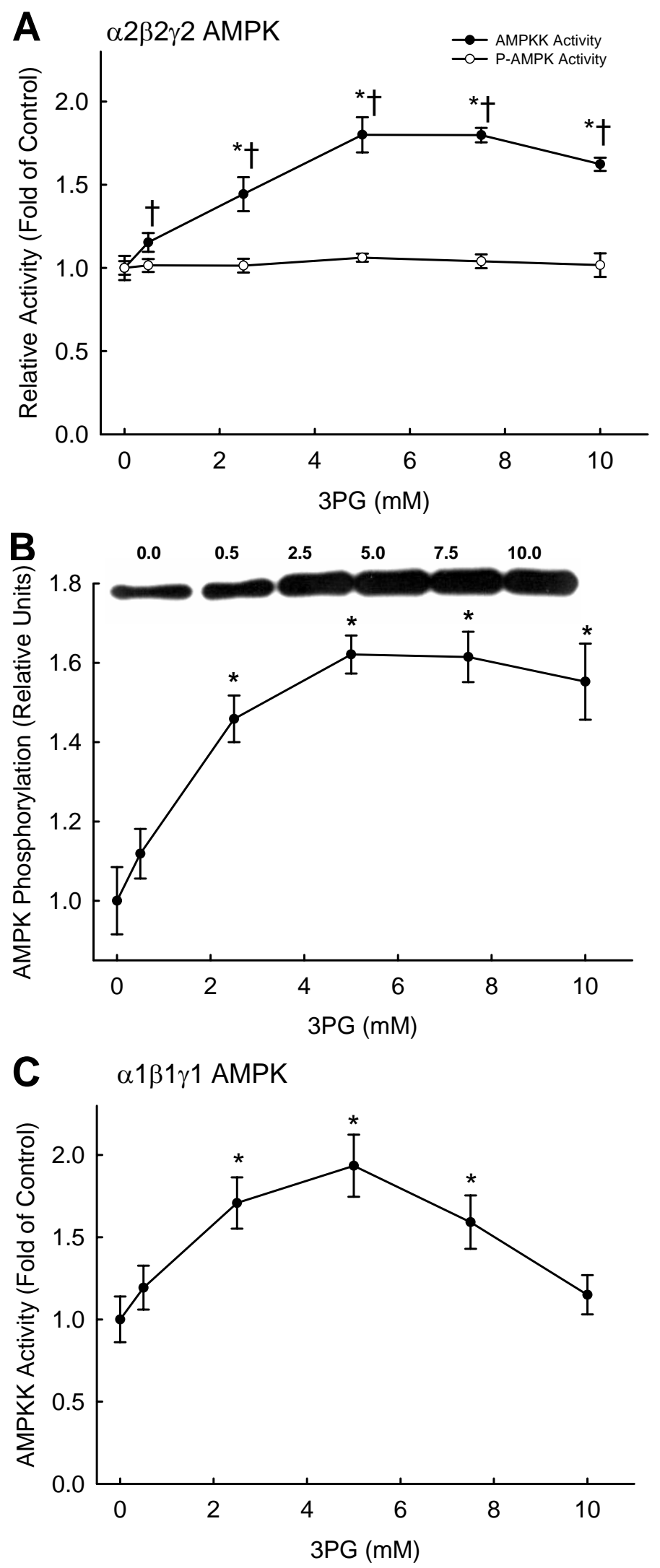
Figure 4

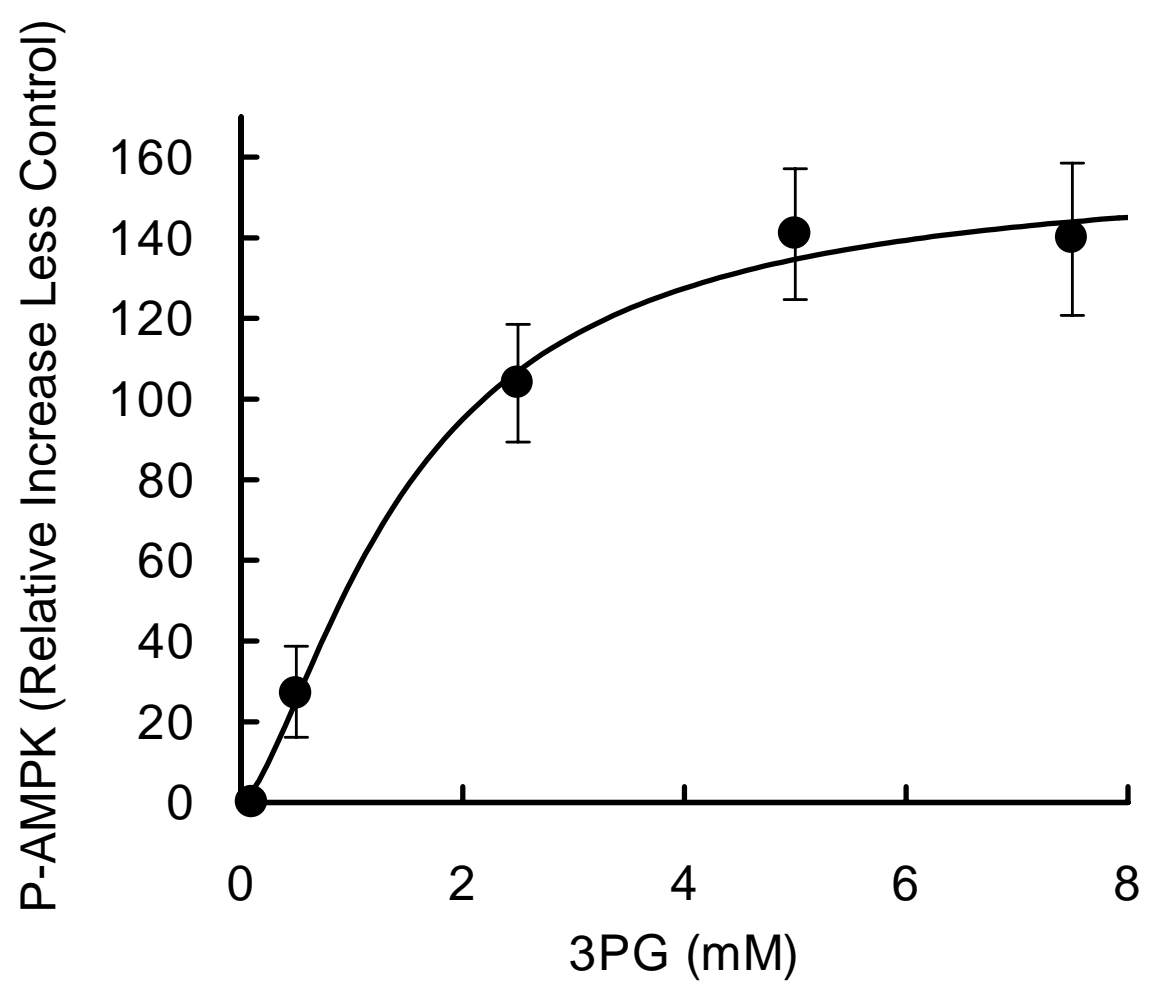


Figure 5

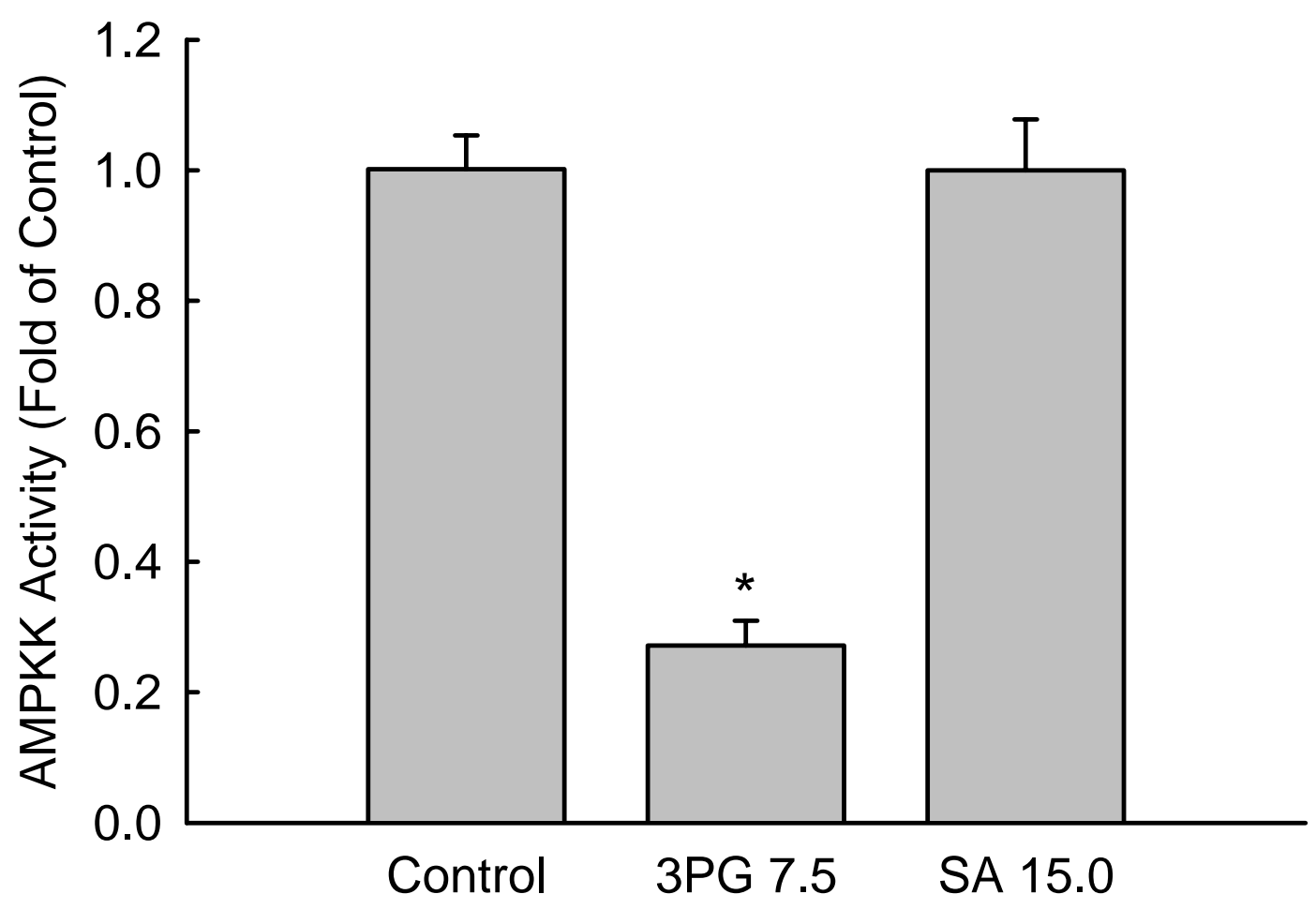


Figure 6

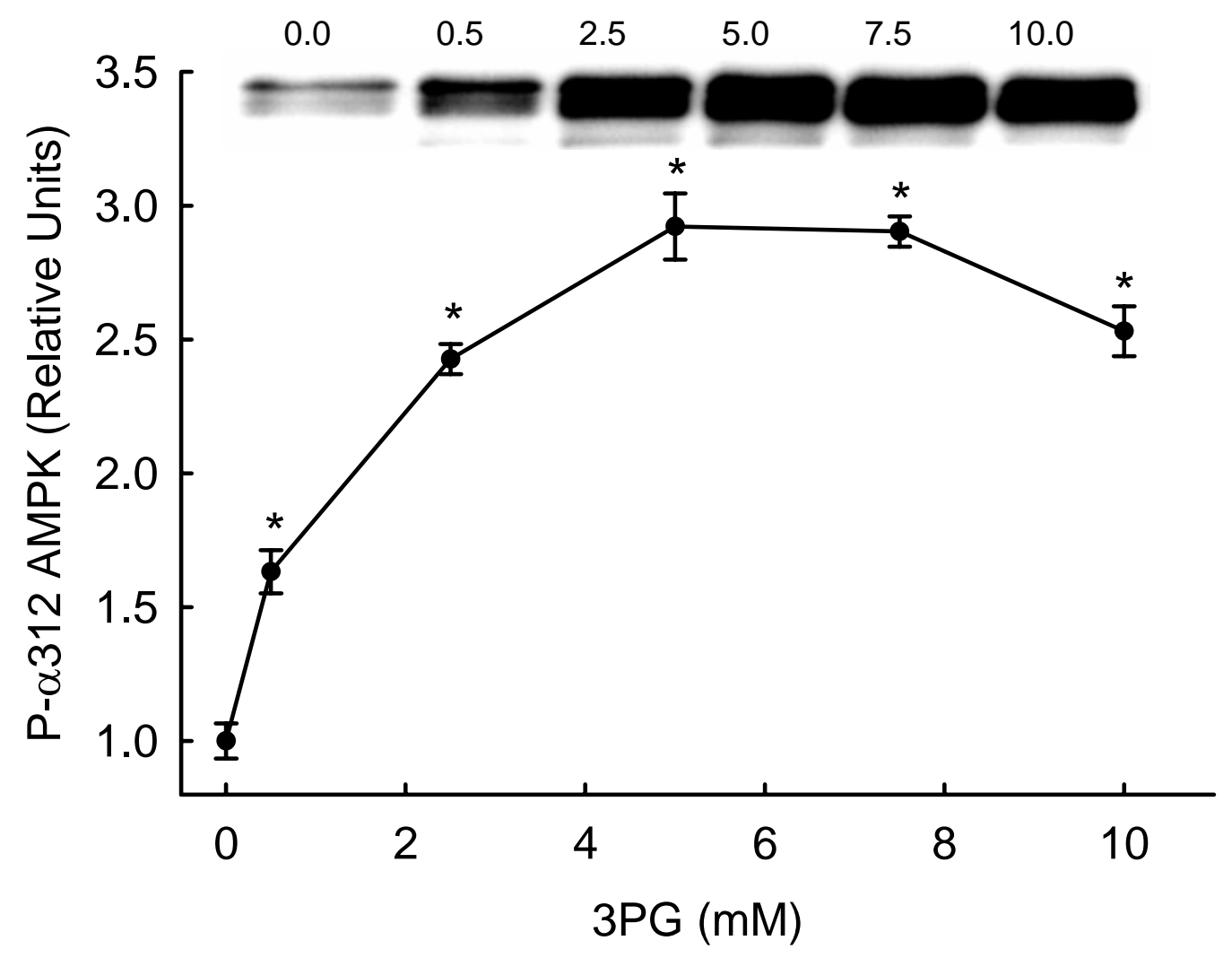


Figure 7
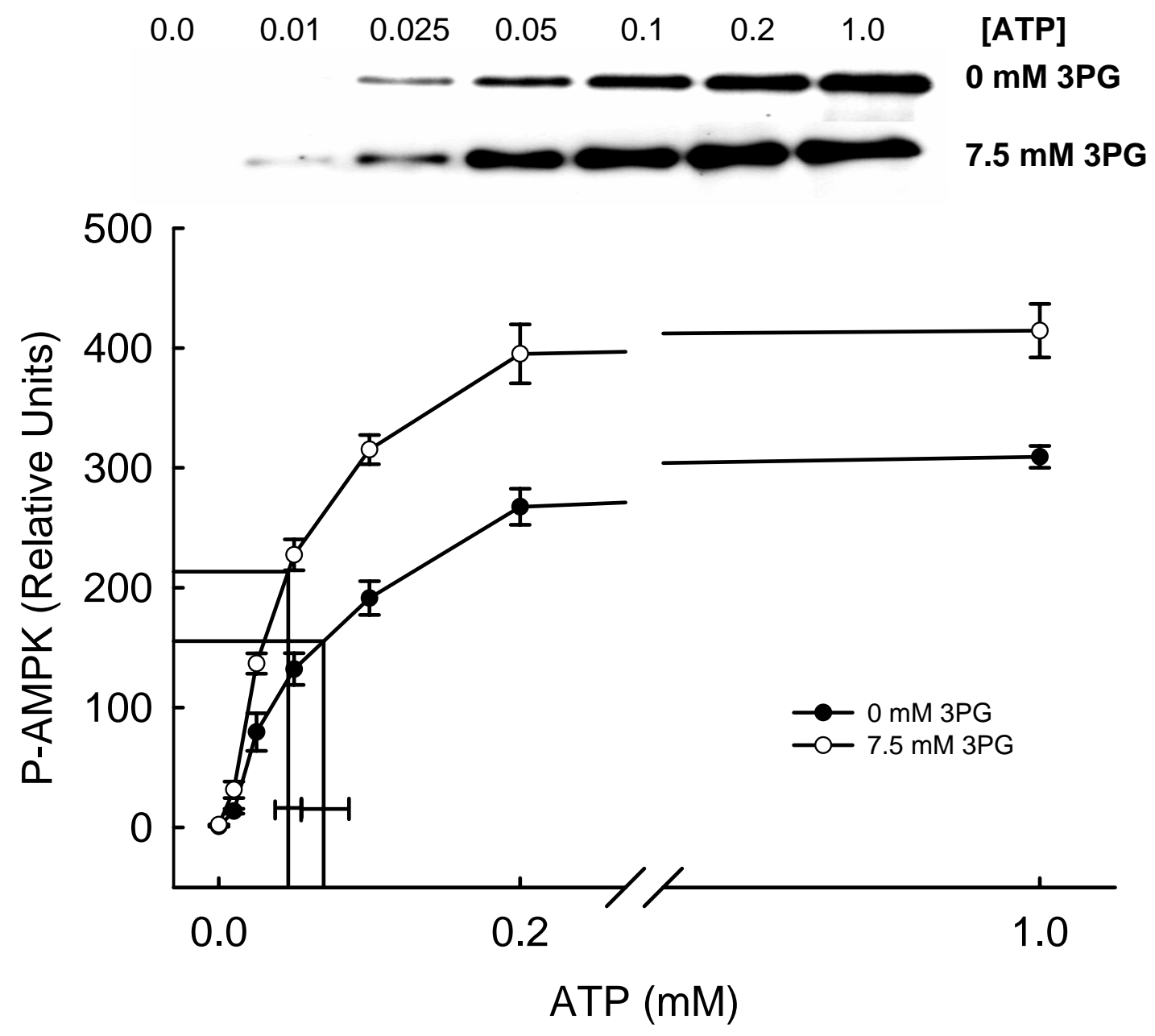


\title{
Curriculum Vitae
}

\author{
William John Ellingson \\ Brigham Young University \\ Department of Physiology and Developmental Biology \\ 574 Widtsoe Building \\ Provo, UT 84602 \\ willellingson@hotmail.com
}

\section{Education}

Brigham Young University

BS, Physiology and Developmental Biology, August 2005

Brigham Young University

MS, Physiology and Developmental Biology, August 2006

\section{Related Experience}

Brigham Young University

Exercise Physiology Lab of Dr. William Winder

Lab Technician, March 2004 to June 2006

Brigham Young University

Histology/Tissue Biology Lab, PDBio 225

Lab Assistant/ Teaching Assistant, January 2004 to April 2006

\section{Honors}

Deans List for the College of Physical and Mathematical Sciences, August 2000 International Student Honor Roll, December 2005

\section{Publications}

Taylor EB, Ellingson WJ, Lamb JD, Chesser DG, and Winder WW. Long-chain acylCoA esters inhibit phosphorylation of AMP-activated protein kinase at threonine-172 by LKB1/STRAD/MO25. Am J Physiol Endocrinol Metab 288: E1055-E1061, 2005.

Taylor EB, Lamb JD, Hurst RW, Chesser DG, Ellingson WJ, Greenwood LJ, Porter BB, Herway ST, and Winder WW. Endurance Training Increases Skeletal Muscle LKB1 and PGC-1 \{alpha\} Protein Abundance: Effects of Time and Intensity. Am J Physiol Endocrinol Metab 289: E960-E968, 2005.

Taylor EB, Ellingson WJ, Lamb JD, Chesser DG, Compton CL, and Winder WW. Evidence against regulation of AMP-activated protein kinase and LKB1/STRAD/MO25 activity by creatine phosphate. Am J Physiol Endocrinol Metab 290: E661-E669, 2006. 